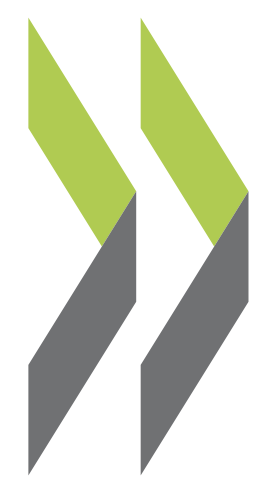

OECD Local Economic and Employment Development (LEED) Papers 2011/11

\title{
Building Flexibility and Accountability Into Local Employment Services: Country Report for Belgium
}

\section{Kristel Bogaerts,}

\section{Hans Echelpoels,}

Wouter Van Dooren, Ive Marx,

\section{Francesca Froy}

https://dx.doi.org/10.1787/5kg3mkv0448s-en 


\section{Building Flexibility}

\section{and Accountability into}

\section{Local Employment Services}

Country report for Belgium

Authored by:

\section{Updated January 2012}

Kristel Bogaerts, Hans Echelpoels, Wouter Van Dooren, Ive Marx, Francesca Froy

University of Antwerp

Herman Deleeck Centre for

Social Policy

Research Group on Public Administration \& Management

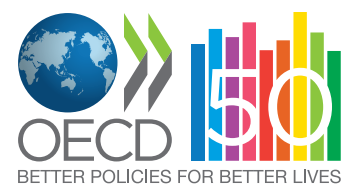




\section{Building Flexibility}

\section{and Accountability into}

\section{Local Employment Services}

Country report for Belgium

Authored by:

Kristel Bogaerts, Hans Echelpoels, Wouter

Van Dooren, Ive Marx, Francesca Froy 


\section{EXECUTIVE SUMMARY}

Flexibility in the delivery of local labour market policy can be identified as "the possibility to adjust policy at its various design, implementation and delivery stages to make it better adapted to local contexts, actions carried out by other organisations, strategies being pursued, and challenges and opportunities faced" (Giguère and Froy, 2009). A local focus refers in this context to an area with 150000 to 800000 inhabitants. Increasing flexibility in the management of labour market policy at the sub-regional or municipal level could lead to programmes that are specifically tailored to local needs, which could improve their effectiveness. Increased flexibility, however, also holds the risk of local programmes diverging from central goals. Therefore, flexibility needs to be accompanied by mechanisms for holding local actors accountable for their policies and actions.

This report explores the accountability and flexibility in labour market policy in Flanders (Belgium) based on a series of indicators on programme design and eligibility criteria, target groups, budgets and financing, goals and performance management, collaboration and outsourcing. The results are based on desk research, an e-survey for organisations involved, interviews with representatives of key organizations and round tables (two at local level, one at central level). The governance framework of the Flanders region is dynamic and changing. Within this framework accountability and flexibility relationships are explored within the VDAB (the Flemish Public Employment Service - PES), the SERR/RESOC network, and the municipalities in Flanders.

Labour law and social security are a federal matter. The regions (Flanders, Wallonia and Brussels) are responsible for active labour market policies, labour mediation and the Public Employment Service in addition to other policy areas. The communities (organised by language) are responsible for person-related matters such as education and policy concerning people with disabilities. A major part of active labour market policy and instruments in Belgium is managed by the federal National Employment Office (NEO, with 30 local antennas in Flanders) and the regional Public Employment Service (VDAB). At the local level, the provinces, cities and municipalities have no explicit competences for labour market policy. They mainly implement federal and regional decisions and actions, but they also have residual competences within the principle of subsidiarity.

Throughout the system there exist extensive advisory networks responsible for consultation and planning. This occurs at the sub-regional level through councils called SERR/RESOC. Flanders is divided in five ERSV territories (identical to the provinces), 13 SERRs and 15 RESOCs. SERR and RESOC operate on a policy level and do not provide client services. Efforts are being made in Flanders to bring together all the different actors engaged in labour market policy. This is supported through a partnership agreement developed in 2005. A key mechanism for bringing together the different actors are the local one-stop-job shops (werkwinkels). These represent a local partnership of PES, Public Social Assistance Centre, Labour Counselling, local employment agencies, NEOs and other local actors. The one-stop-shops provide integrated services on work and employment, and information on the local service economy. The Flemish government is currently undertaking an ambitious reform agenda to reduce institutional crowdedness, as well as improve regional governance and local governance capacity. At the same time, the VDAB is undergoing a process of internal restructuring. 
The Flanders Public Employment Service, VDAB (Vlaamse Dienst voor Arbeidsbemiddeling) is accountable to the Flemish government. They are responsible for registration and placement of jobseekers as well as for vocational training. VDAB has a central office, 13 sub-regional local labour market management offices (the working area of which corresponds to the OECD definition of a local labour market) and six provincial competence centres (provinciaal competentiecentrum).

Flanders operates a relatively centralised PES. Employment and activation measures are designed and financed on the federal or regional level but are implemented on the local or sub-regional level. Thus, the flexibility of local labour market management offices is weak on programme design, definition of eligibility criteria and definition of target groups. The local offices only have flexibility in relation to a small proportion of their budget to support local projects to cover specific local needs. Targets and performance measurement are set centrally, based on the management agreement between the VDAB and the Flemish government. Taking into account the assignment of the VDAB, the local offices, however, can implement and use the (centrally) provided measures and instruments with a certain degree of discretion.

The 13 regional labour market offices have limited flexibility in the way that they spend their budgets. It is possible to outsource locally but most tendering is centralised, and locally specific tenders are also often decided at the central level. Because of its relatively centralised management design, the VDAB system is clearly an efficient organisation in meeting the needs of individuals and firms, and this is welcomed by the social and sectoral partners at Flanders government level. However, it may make the organisation less adaptable to tackling opportunities and challenges at the level of local communities and local labour markets.

Within the overall framework, the VDAB makes a strong effort to be both collaborative and active at the local level, an attitude supported by an emphasis on openness from the leadership of the organisation. There is clearly room, however, for discretion for local offices. Despite the plethora of partnerships and networks, until recently many local networks involving the VDAB seemed primarily to circulate information (what are we doing?) or have coordination functions (who does what?). Collaborative networks that develop a joint policy and implement joint actions for a local labour market (what will we do?) seem to be rare.

The tripartite consultation platforms RESOC and SERR cover the development of strategic objectives for employment policy at the sub-regional level. This level is not involved in the delivery of active labour market policy for individuals, but rather operates at a strategic level. Their task is to give advice on certain issues, analyse the local labour market context, develop a regional employment plan (streekpact) and to coordinate regional cooperation on labour market issues. The work of RESOC and SERR appears to weakly feed into the development of policies and programmes in an ad-hoc fashion.

The local authorities can take initiatives on matters of local importance, such as local labour market policy. However, they do not receive special financing for this type of policy. Some municipalities have more ambitions in this field than others. In particular the Flemish cities are eager to take up a role in defining local policies, which raises the issue of local governance capacities.

The overall perception of flexibility available to labour market actors (VDAB and the RESOC/SERR) was perceived to be moderate to high by respondents to the OECD e-questionnaire. However, they felt that their influence on budget management was somewhat lower. The PES offices indicated that the flexibility they received from the central PES division was adequate and improving. They also pointed to the ongoing internal reform of the PES as an opportunity to further improve flexibility in meeting the needs of local labour markets. The RESOC/SERR have freedom in addressing local labour market issues. The limitation they reported is their weak influence on the development of programmes and policies, in combination with the lack of their own core funding to implement policies themselves. 
Assessing the sub-regional flexibility available to local employment agencies in Flanders within the framework of the OECD criteria indicates that there is still room for further flexibility at the local level. Concerning the PES, it would be worthwhile to consider (1) strengthening the possibilities for local projects and other local initiatives, (2) allowing for strategic choices in organising collaboration at the local level, and (3) reducing the top down defined collaboration networks/allowing for more tailor-made collaborations.

The current reform of the VDAB brings the management responsibility to a higher geographical level from sub-regions to provinces. This could be a useful opportunity to create more flexibility and strategic responsibility for the VDAB at the provincial level, in combination with the introduction of regional and city managers. The VDAB will have to find ways of dealing with non-equivalent partners in terms of budgets and capacity (such as small municipalities). Moreover, it would be considered whether the performance contracts of the provincial directors could contain a flexibility clause requiring them to take differences in local labour markets into account and encouraging them to tailor programmes and policies to meet them. Finding a way to adapt the policies of the VDAB better to large cities, and ensuring that VDAB programmes and projects tie in further to city-based strategies is another priority.

To maintain accountability, the outcome-based approach to performance management in the VDAB promises to provide greater leeway to local offices while preserving the achievement of province wide goals. In particular, the VDAB sees target setting as a factor in creating a learning environment as opposed to a sanctioning one. International examples of good practice can further inspire the VDAB to provide good results while introducing more flexibility on local targets. Examples given are the introduction of feedback systems (Alberta, Canada), set additional local targets in agreement with local partners (Texas, US) or to balance horizontal and vertical lines of accountability (Denmark).

The strategic planning documents designed by RESOC and SERR currently feed into the development of policies and programmes in an ad-hoc and relatively weak way. There seems also to be a lack of close working between the RESOC and SERR and the VDAB at a local level. Research by the RESOC and SERR into local labour market challenges and opportunities is clearly valuable. However, in the future it should be evaluated as to whether this is the right mechanism for collecting information and planning strategies, if there is no clear link back into the policy development process.

Labour market agencies cannot work alone in tackling complex labour market issues. It is therefore not just labour market policy that needs to be flexible. In Flanders, it is clear that the compartmental nature of government has not helped when trying to tackle difficult issues in a holistic manner at the local level. A number of attempts have been made to help break out of policy silos through emphasizing both a client perspective and an area-based perspective. Collaboration has been supported at many different governance levels in Flanders, making the labour market policy planning process very complicated. More reflection on the right level for implementing labour market policy would be useful. This also refers to the issue of raising capacities. Central governments often fear that local capacities are low and are reluctant to offer new responsibility and hence new resources. However, without gaining responsibility and a degree of control over policy implementation, local actors often have little opportunity to build their competences. Incremental flexibility could be useful in Flanders to give additional responsibilities to municipalities which already have a capacity to deliver, while encouraging others to also build their critical mass. 
TABLE OF CONTENTS

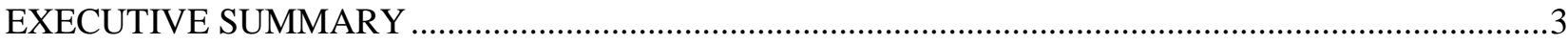

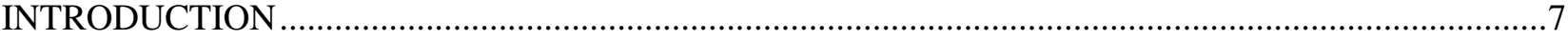

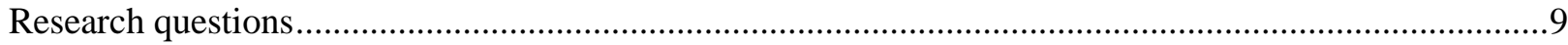

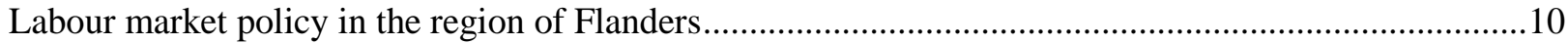

Variation in the labour market context in different parts of Flanders..................................................11

The institutional landscape in Flanders: organisations and instruments ................................................16

ANALYSING THE FLEXIBILITY WITHIN THE FLEMISH SYSTEM..............................................27

Methodology: Description of the survey, interviews and round tables ...................................................27

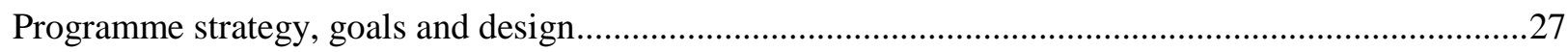

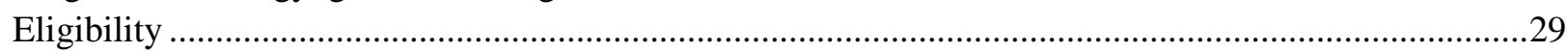

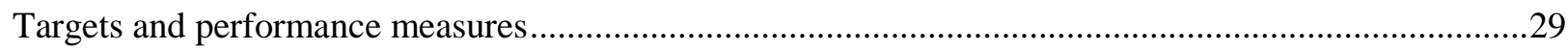

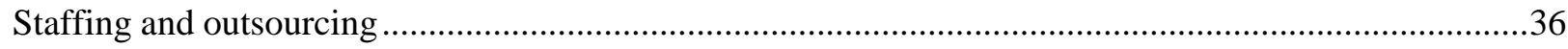

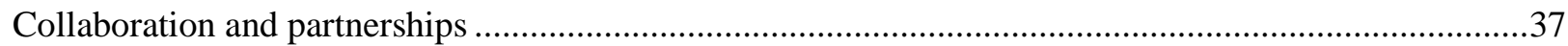

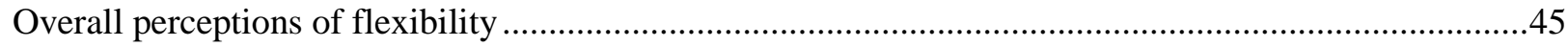

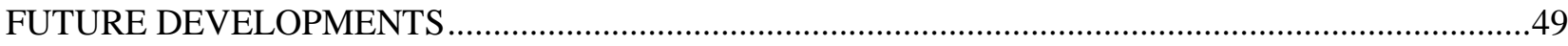

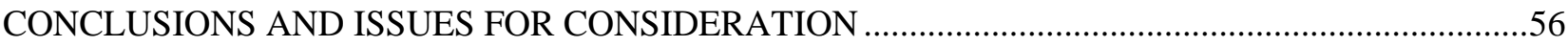

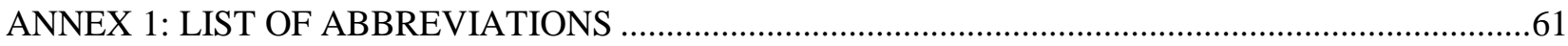

ANNEX 2: INTERVIEWEES AND ROUNDTABLE PARTICIPANTS …...............................................63

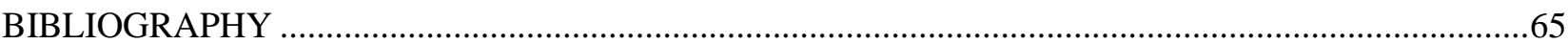




\section{INTRODUCTION}

The Organisation for Economic Cooperation and Development (OECD) and its Local Economic and Employment (LEED) Programme is conducting a study on "Managing Accountability and Flexibility in Labour Market Policy" in four countries: Belgium (Flanders), Canada, Denmark and the Netherlands to identify:

- What degree of flexibility is available at the local and regional level regarding active labour market policy measures?

- How can more flexibility at the local level go together with more effective policy measures while preserving accountability and the achievement of national policy goals?

The OECD has commissioned country reports that describe the national situation in each country, based on desk research, an OECD e-questionnaire, a series of interviews and roundtables with actors in local and central labour market policies as part of OECD study visits.

Flexibility is defined in the context of the study as "the possibility to adjust policy at its various design, implementation and delivery stages to make it better adapted to local contexts, actions carried out by other organisations, strategies being pursued, and challenges and opportunities faced" (Giguère and Froy, 2009). It should be clear that the OECD does not refer to flexibility of the labour market itself, but to flexibility in the management regimes for designing and implementing labour market policy. These regimes contain legal, budgetary and performance management-related elements.

The OECD (Giguère and Froy, 2009) has developed a series of indicators to assess the degree of regional and sub-regional or local flexibility in labour market policy.

- $\quad$ Programme design refers to the input that sub-regional offices have in the design of policies and programmes and their ability to formulate their own programmes.

- A second indicator is the degree to which sub-regional actors can specify which target groups are eligible for their programmes and policies.

- The amount of flexibility that local actors have in goals and performance management and to what extent they can set their own targets makes up a third indicator.

- The freedom to collaborate with various other (local) actors and to form partnerships with them is also reviewed.

- Flexibility in financing is important, referring to the flexibility that sub-regional and local actors have to appropriate their budgetary resources to suit local needs.

- Finally, it is investigated the extent to which local offices can make decisions about outsourcing services to external providers. 


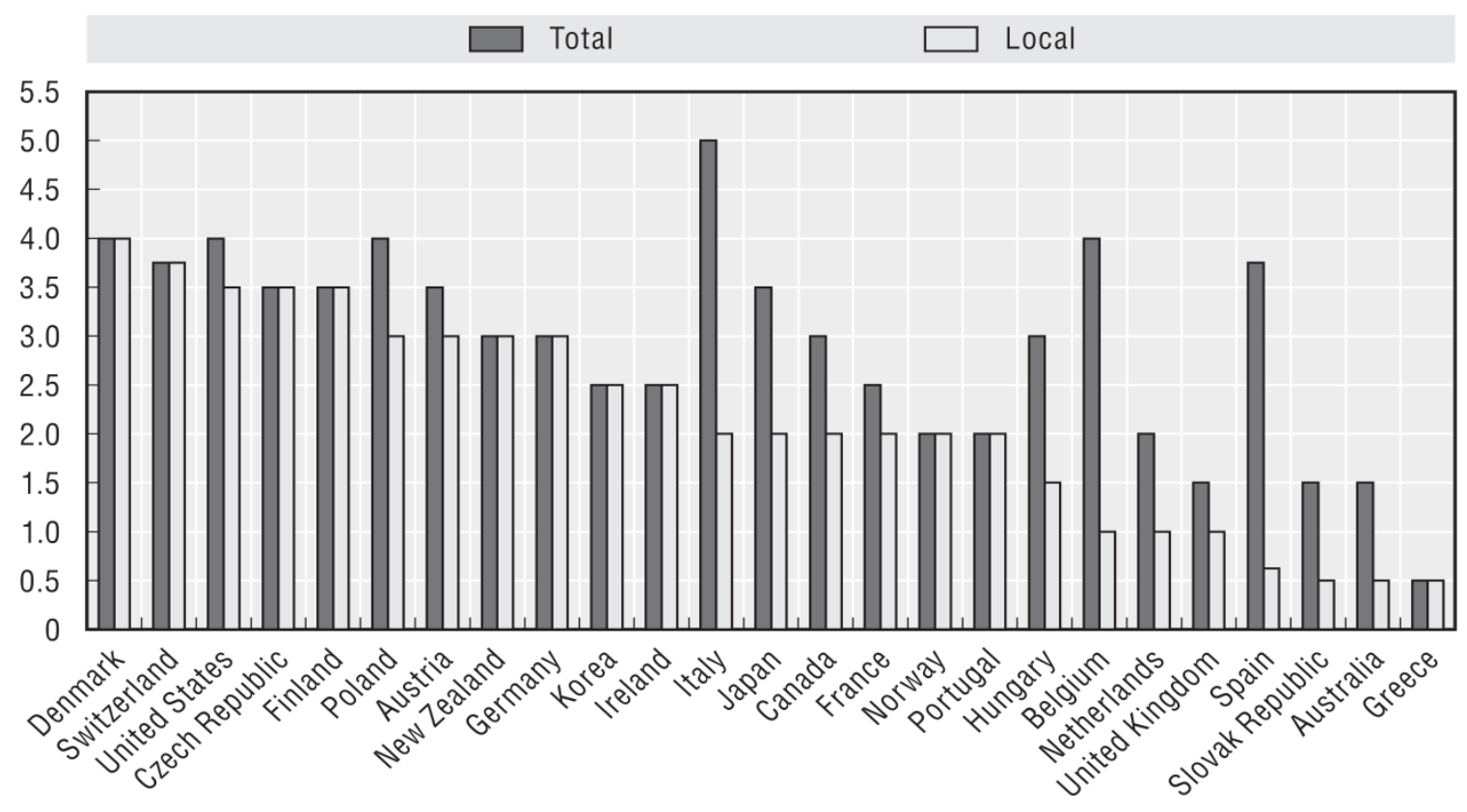

Source: OECD, 2009:26

In 2009 the OECD applied these indicators to 25 member countries. A score between 0 and 5 is assigned to a policy level. For Belgium, the regional level proved to be very flexible, with a score of 4/5. The sub-regional or local level, on the other hand, only scored 1 point out of 5 . While the Belgian regions (Brussels, Flanders and Wallonia) have been given a large degree of flexibility with regards to labour market policy, the manoeuvring room for sub-regional entities was significantly lower. The sub-regional offices of the VDAB were identified as having a limited amount of flexibility in designing and choosing their own labour market programmes, although there are many possibilities for these offices to be involved in partnerships with other labour market actors. The OECD asserted that federalisation gave significant freedom to regions, but that regions appeared reluctant to pass this discretion on to the local levels.

By local, the OECD refers to the level of local labour markets - sometimes known as "travel to work areas" , where economic development strategies are frequently designed and where local policy makers have the opportunity of a strong level of contact with local businesses, sectors and clusters in addition to non-governmental organisations and community groups. This does not necessarily correspond to the municipal level, where the public employment service has its antennas. In order to reflect this territorial subtlety, the OECD distinguishes between three levels of government and/or administration, when the size of the country permits: 
- Regional level: administrative regions with a population of between 800000 and 3 million (Territorial level 2 or NUTS 2, following the nomenclature used by the European Union, although in Belgium the three main regions, Brussels, Flanders and Wallonia are actually classified as NUTS 1).

- Sub-regional level: smaller regions with a population of between 150000 and 800000 (Territorial level 3 or NUTS 3).

- $\quad$ Local level or municipal level: localities under 150000 (Territorial level 4 or NUTS 4).

The focus here is on the sub-regional level (smaller regions with a population of 150,000 to 800000 ), which approximately corresponds to the 13 VDAB sub-regional labour offices.

Increasing flexibility in the management of labour market policy at the sub-regional or even municipal level could lead to programmes that are specifically tailored to local needs, which could improve their effectiveness. Increased flexibility also holds certain dangers, however, such as the risk of local programmes diverging from central goals. To reduce such risks, flexibility needs to be accompanied by mechanisms for holding local actors accountable for their policies and actions. Mosley (in OECD 2009:8687) identifies four types of accountability for public agencies: legal accountability (public agencies being expected to act on the basis of the rule of law and in conformity with applicable regulations), fiscal accountability (correctness and efficiency in the use of finances), performance accountability (outputoriented effectiveness and efficiency), and public accountability (responsiveness to the needs of citizens and other stakeholders).

\section{Research questions}

The OECD has defined a set of research questions to support the international comparability of the review:

Programme design and eligibility: Can local employment offices and municipalities design or adapt labour market policies and programmes to meet the needs of local business and local communities?

Financing: What freedom do local employment offices and municipalities have in spending their budgets? Can they use their budgets to work in partnership with other local actors?

Goals and performance management: To what extent are organisational goals and targets for active labour market policy centrally determined? Are targets and indicators negotiated locally?

Collaboration: Can local offices decide who they collaborate with locally? Are they able to fully contribute to local employment and economic development strategies? (...)

Outsourcing: To what extent can local offices influence the process of outsourcing of activities to other labour market actors?

These questions will be answered in detail in chapter 5 . In the meantime, the report will give some background on the institutional framework for organising labour market policy in Flanders and on the labour market context. 


\section{Labour market policy in the region of Flanders}

Figure 1 provides an overview of the actors involved in local labour market policy in Flanders. This figure only includes the actors (and their decentralised units) that are directly involved in policy making in this domain. Actors in related domains, such as trade unions, sector organisations, educational platforms, mutual organisations and similar are not included.

Figure 1. Overview of actors involved with local labour market policy.

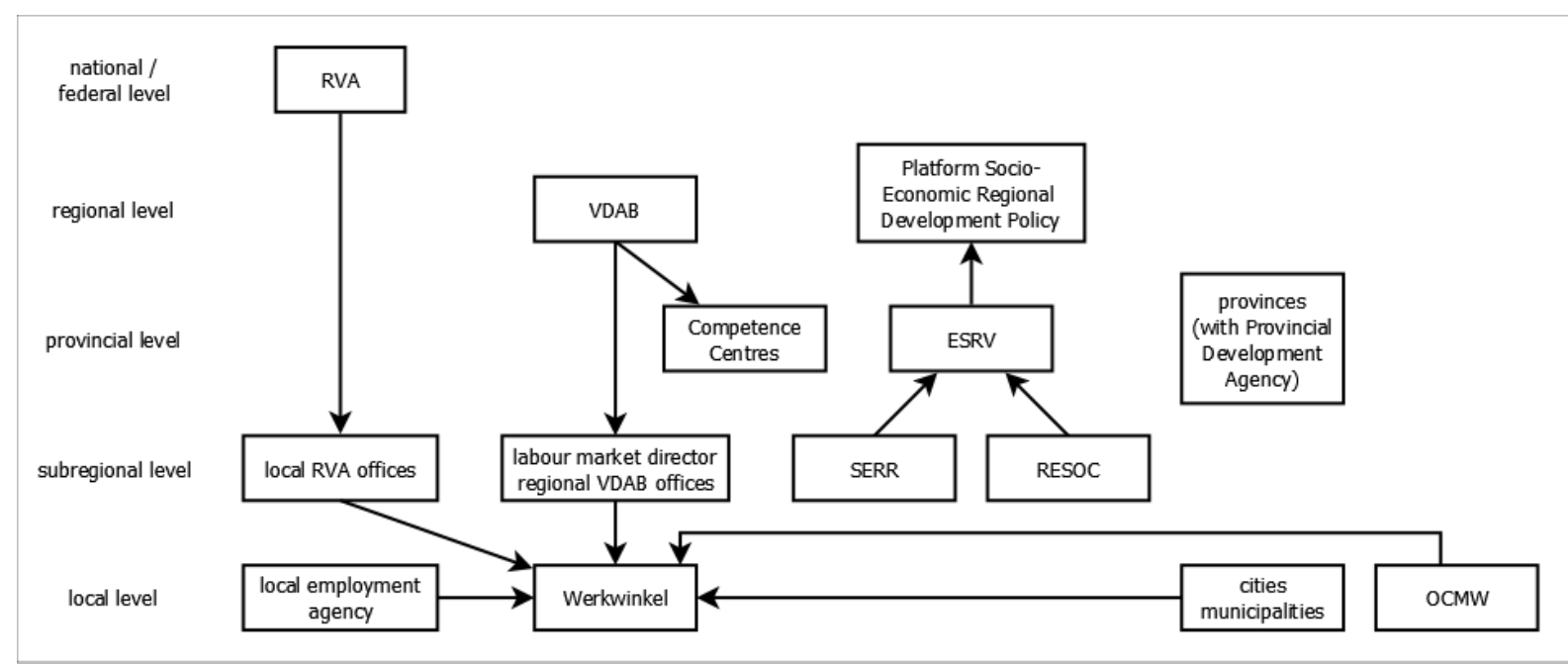

\section{Competences: division of powers in Belgium}

Belgium is a federal country in transition. Since the late 1970s, five consecutive reforms have transferred competences from the then unitary Belgian level to regions and communities. This has been carried out in a relatively piecemeal way and as a result, the division of powers nowadays is rather complicated. In the area of work and labour market policies, the institutional setup is as follows:

Labour law and social security (legislation, organisation, financing and administration) are a federal matter. Issues of social security have never been subject of devolution so far.

The regions (organised by territory: Flanders, Wallonia and Brussels) are mainly responsible for territorial matters such as economy and employment. They are responsible for active labour market policies (sometimes co-financed by the federal government) and for labour mediation and the Public Employment Services.

The communities (organised by language: Dutch, French or German speaking) are responsible for person-related matters such as education (including social promotion and vocational training and retraining) and policy concerning handicapped persons. The Flemish government cannot elaborate labour market actions that belong to the competences of the federal level and vice versa.

The provinces, cities and municipalities have no explicit competences for labour market policy. They mainly implement federal and regional decisions and actions. But, following the Belgian constitution, they do have residual competences. This means that they can take all actions of local importance. This also counts for local labour market policy. The principle of subsidiarity is important here. What a smaller entity can do or perform sufficiently must not be done by a larger entity, unless the latter one can do this more appropriate. 
The Flemish government uses its regional and community competences to elaborate a Flemish labour market policy. As for all other countries and regions, Flanders has to comply with European legislation and advice (e.g. the Lisbon strategy).

Advice and decision making with regards to the socio-economic domain is part of collective bargaining in a strong network of institutions with an important role for social partners such as trade unions and employers' organisations. These institutions are based on the principle of parity between the partners. In the collective bargaining process, the trade unions are considered to be representatives of the employed and the unemployed. It should be noted that the payment of the federally assigned unemployment benefits is organised (mainly) by the trade unions. Representatives of trade unions and employers' organisations are also members of the management committee of different organisations, including the National Employment Office and the regional PES's.

Belgium cannot be considered as one labour market as there exist important differences between the regions (Flanders - Wallonia - Brussels). Employment and unemployment rates, but also the characteristics of labour supply and demand vary significantly. Moreover, not only the unemployment rates, but also the profiles of the unemployed are different. The differences have triggered a public and political debate on financial transfers between the regions and the regionalisation of (some parts) of the social security system.

Also within Flanders, local labour markets differ considerably and along the same lines; different unemployment rates, different supply and demands for jobs, different profiles of the unemployed. A brief analysis of the labour market contexts of Kortrijk and Antwerp illustrate this point well.

\section{Variation in the labour market context in different parts of Flanders}

Even although Flanders is a fairly small region, there is significant internal variation in employment indicators. For example, in January 2011, the mean unemployment rate for Flanders was 6.99\%. For subregion Kortijk-Roeselare, this was only 4.98\%, while for sub-region Antwerpen-Boom this number was $10.30 \%$. These two sub-regions are especially interesting because they represent the two extremes of unemployment evolution in Flanders: unemployment in Kortrijk-Roeselare fell $11.4 \%$ between January 2010 and January 2011, by far the most significant fall in Flanders; in Antwerpen-Boom, on the other hand, there was only a $0.5 \%$ reduction in unemployment, the poorest result in Flanders. 
Figure 2. Regional unemployment rates, January 2011, Flanders.

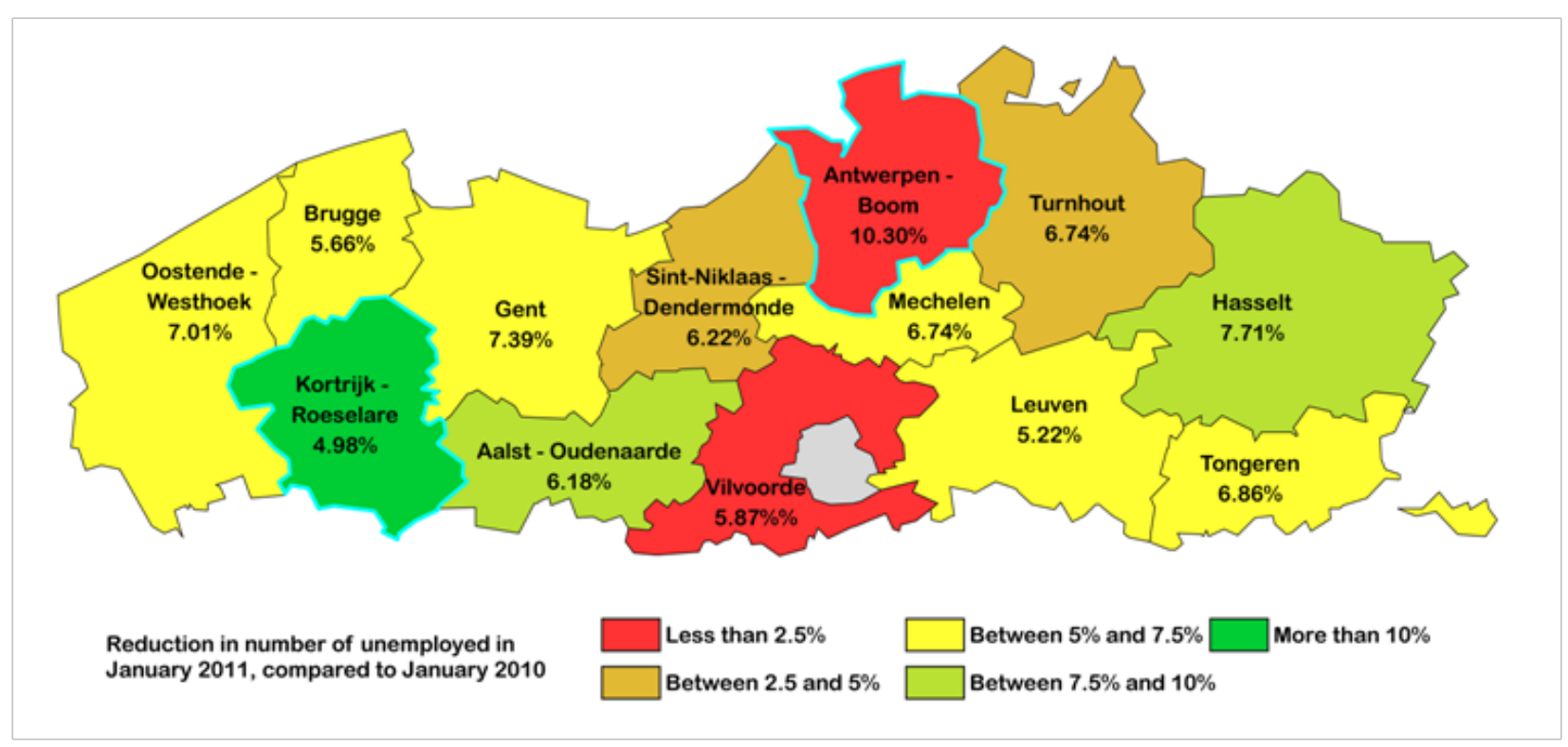

Source : ARVASTAT VDAB, with own editing 
Table 1. Characteristics of the unemployed jobseekers in Flanders, Kortrijk-Roeselare and Antwerp, January 2011

\begin{tabular}{|l|c|c|c|}
\hline & Flanders & $\begin{array}{c}\text { Kortrijk- } \\
\text { Roeselare }\end{array}$ & $\begin{array}{c}\text { Antwerpen- } \\
\text { Boom }\end{array}$ \\
\hline Full unemployed & $75.8(-7.5)$ & $73.6(-15.3)$ & $71.3(-4.3)$ \\
\hline $\begin{array}{c}\text { Jobseekers in qualifying } \\
\text { period }\end{array}$ & $6.6(-7.6)$ & $6.2(-13.7)$ & $5.8(-2.4)$ \\
\hline Voluntary inscriptions & $9.4(+5.1)$ & $8.4(-1.0)$ & $13.7(+22.6)$ \\
\hline Other & $8.2(+9.6)$ & $11.8(+14.7)$ & $9.1(+3.5)$ \\
\hline \hline Men & $52.1(-6.6)$ & $48.7(-13.0)$ & $55.8(-0.3)$ \\
\hline Women & $47.9(-3.8)$ & $51.3(-9.8)$ & $44.2(-0.8)$ \\
\hline \hline Up to 25 years old & $20.4(-9.0)$ & $21.5(-13.3)$ & $19.4(-7.2)$ \\
\hline 25 to 50 years old & $53.3(-7.1)$ & $48.3(-15.6)$ & $57.5(-0.4)$ \\
\hline \hline 50 years or older & $26.3(+2.3)$ & $30.2(-2.1)$ & $23.1(+5.6)$ \\
\hline Low skilled & $51.3(-5.1)$ & $56.0(-10.4)$ & $51.7(+0.0)$ \\
\hline Medium skilled & $33.7(-5.9)$ & $31.0(-13.9)$ & $33.7(-0.9)$ \\
\hline \hline High skilled & $15.0(-4.1)$ & $13.0(-9.6)$ & $14.7(-1.5)$ \\
\hline \hline Up to 1 year of \\
unemployment & $55.9(-9.4)$ & $54.1(-17.0)$ & $55.3(-3.8)$ \\
\hline 1 to 2 years of \\
unemployment
\end{tabular}

$\%$ of total unemployed jobseekers - January 2011 (in brackets: \% change compared to January 2010) Source: ARVASTAT VDAB

\section{Sub-region Kortrijk}

In Flanders, immigrants whose current or previous nationality is not one of the EU or EVA countries are called 'allochtoon'. This group tends to have more difficulties in the Flemish labour market. In the Kortrijk region, $18.6 \%$ of unemployed people are allochtonen, significantly less than the Flemish mean of $24.0 \%$. This might be because immigrants tend to rely heavily on social networks of people with similar origins shortly after arriving in a host country, and these networks are more often found in big cities or regions with a history of labour migration. Being located close to the French border, Kortrijk has attracted many French workers. This has been greatly facilitated by the fiscally beneficial employment statute that these 'border workers' could enjoy. However, France and Belgium recently decided to gradually abolish this statute, meaning that working in Belgium is likely to become less attractive to French workers in the near future. 
Compared to Flanders, there is a slightly higher proportion of younger and older unemployed persons in the Kortrijk region: $21.5 \%$ versus $20.4 \%$ and $30.2 \%$ versus $26.3 \%$ respectively. Possible explanations for this phenomenon can be found in the structure of the Kortrijk economy. The west of Flanders has historically been an important producer of flax and has therefore relied heavily on the textile industry. In the past few years, this industry has been in decline: whereas it employed 56,152 persons in all of Belgium in 1999, this number had shrunk to only 38,620 in 2006. This led to an influx of older, lower educated manual workers into the unemployed population. Although the textile industry may have declined, there is still a large presence of other traditional industries, such as metal processing and construction. The local construction sector indicates that it experiences difficulties in attracting young employees, despite a high youth unemployment rate. In addition to these 'old' industries, the region has also been attracting new and innovative companies in the field of product design and product development. Such new-tech companies are primarily looking for higher skilled employees with a secondary education degree.

The relative amount of low-skilled job-seekers is higher in the Kortrijk region than it is in Flanders, at $56.0 \%$ (versus 51.3\%). As stated earlier, the decline of the textile industry has in particular created unemployment amongst low-skilled persons. Furthermore, the higher education opportunities in Kortrijk are fairly limited. The region houses the only university in West-Flanders (Kulak), which is actually an offshoot of the Catholic University of Leuven (KUL). At the moment, the Kulak only offers the first and second years of a Bachelor degree, forcing students to study in another city in order to complete their education. This causes a brain drain, with many high-skilled young people not returning to West-Flanders to build their career.

Compared to Flanders, a greater proportion of unemployed people in the Kortrijk region have been unemployed for over 2 years (28.9\% versus 26.4\%). There are a significant group of unemployed persons that are proving hard to reach. People in the region seem to want to work within a fairly limited radius from their home, restricting the number of vacancies they express an interest in.

At the same time, the Kortrijk region experiences problems with skills shortages and difficulties in filling existing vacancies. The active population is ageing, there is an unmistakeable brain drain of highskilled young people to other regions, a noticeable group of unemployed are proving difficult to re-engage in the labour market, and the supply of French border workers is expected to decrease significantly in the next several years. On top of that, many unemployed people in the Kortrijk region are persons who have a labour market profile that makes them less attractive to prospective employers, such as low-skilled and older workers. These factors, along with the structural mismatch between employee capacities and employer requirements, is restricting the possibility for the Kortrijk economy to sustain its growth.

\section{Sub-region Antwerpen-Boom}

Antwerp, with over 480,000 inhabitants, is the biggest city of Flanders, and as such has very different labour market needs from the rest of the region. Nevertheless, it is grouped together with many nearby municipalities into the VDAB-region Antwerpen-Boom. In the following paragraphs, we will discuss both the labour market situation at the level of the VDAB-region ('region of Antwerp') and at the level of the city ('city of Antwerp').

Looking solely at the city of Antwerp, $16.0 \%$ of the population was unemployed in July 2010, compared to 7.9\% for Flanders. Between July 2009 and July 2010, unemployment in Antwerp rose with $0.7 \%$. However, at the same time available vacancies increased by $42.4 \%$, far greater than the rest of the region (the corresponding figure was $28.8 \%$ for Flanders). Furthermore, there is a higher than average availability of jobs in Antwerp. For every 100 inhabitants, there are about 94 jobs available, compared to 67 on average for Flanders. However, the employment rate is fairly low at $59.8 \%$, compared to $65 \%$ for 
Flanders (and well under the EU-benchmark of 70\%). This discrepancy exists because of the large numbers of commuters that work in Antwerp but live in the surrounding municipalities.

Table 2. Characteristics of the unemployed jobseekers in the Antwerp region and city, January 2011.

\begin{tabular}{|c|c|c|}
\hline & $\begin{array}{c}\text { Region of Antwerpen- } \\
\text { Boom }\end{array}$ & City of Antwerpen \\
\hline Full unemployed & $71.3(-4.3)$ & $70.3(-3.8)$ \\
\hline Jobseekers in qualifying period & $5.8(-2.4)$ & $4.8(-4.3)$ \\
\hline Voluntary inscriptions & $13.7(+22.6)$ & $14.7(+19.8)$ \\
\hline Other & $9.1(+3.5)$ & $10.1(+1.7)$ \\
\hline Men & $55.8(-0.3)$ & $57.5(-0.5)$ \\
\hline Women & $44.2(-0.8)$ & $42.5(-0.3)$ \\
\hline Up to 25 years old & $19.4(-7.2)$ & $18.5(-8.7)$ \\
\hline 25 to 50 years old & $57.5(-0.4)$ & $61.7(+0.3)$ \\
\hline 50 years or older & $23.1(+5.6)$ & $19.8(+6.2)$ \\
\hline Low skilled & $51.7(+0.0)$ & $54.3(-0.7)$ \\
\hline Medium skilled & $33.7(-0.9)$ & $32.3(-0.1)$ \\
\hline High skilled & $14.7(-1.5)$ & $13.4(+0.2)$ \\
\hline Up to 1 year of unemployment & $55.3(-3.8)$ & $54.3(-3.8)$ \\
\hline 1 to 2 years of unemployment & $19.3(-3.3)$ & $20.3(-3.3)$ \\
\hline Over 2 years of unemployment & $25.4(+10.2)$ & $25.4(+10.4)$ \\
\hline Non-EU & $17.1(+5.9)$ & $21.7(+5.0)$ \\
\hline Immigrants & $37.8(+2.9)$ & $48.2(+4.4)$ \\
\hline Blue collar & $57.9(+1.0)$ & $62.7(+1.0)$ \\
\hline White collar & $42.1(-2.6)$ & $37.3(-2.7)$ \\
\hline Disabled (broad definition) & $8.8(+0.3)$ & $8.4(+0.3)$ \\
\hline Disadvantaged groups & $77.5(+0.8)$ & $81.3(+0.2)$ \\
\hline
\end{tabular}

$\%$ of total unemployed jobseekers - January 2011 (in brackets: \% change compared to January 2010) Source: ARVASTAT VDAB

A large proportion of the unemployed population in Antwerp comes from an immigrant background: $37.8 \%$ for the region, and $48.2 \%$ for the city of Antwerp. Compared to an average of $24.0 \%$ in Flanders, these numbers are very high. There are also noticeably more unemployed persons between 25 and 50 in the Antwerp region (57.5\%) than on average in Flanders (53.3\%). The results for the city of Antwerp are higher still, at $61.7 \%$.

$19.4 \%$ of the Antwerp region unemployed persons are younger than 25, as opposed to $20.4 \%$ in Flanders. For the city, this number is further reduced to $18.5 \%$. Both the city and the local VDAB office are engaging intensely in several programmes to reduce youth unemployment. The amount of persons who have been unemployed for at least two years is slightly lower in Antwerp than in Flanders. Both for the city and for the region, this number is $25.4 \%$, compared to $26.4 \%$ for Flanders.

Results for the region of Antwerp and Flanders are fairly similar with regards to education: $51.7 \%$ of Antwerp region unemployed persons are low-skilled, compared to 51.3\% for Flanders. In the city, however, things are slightly different: here, the low-skilled unemployed make up $54.3 \%$ of the total unemployed population, suggesting a mismatch between this part of the labour force, and the types of 
vacancies which exist in logistics, transportation and storage and the petrochemical industries (associated with Antwerp being a port city). The city of Antwerp is home to the second largest university of Flanders, next to a total of five colleges that are based in the region. The presence of these institutions allows the region to offer a wide selection of post-secondary education options.

\section{The institutional landscape in Flanders: organisations and instruments}

The division of competences in Flanders creates a complex landscape of different actors and organisations operating on various policy levels. Local labour market policy instruments and activities take many forms, and are delivered by a network of institutions, platforms, partnerships, counsels and cooperation mechanisms.

\section{The regional level}

The majority of labour market activation measures in Belgium are managed at the regional level, by four Public Employment Services (PES's) cover the Belgian territory: VDAB in Flanders, FOREM in Wallonia, Actiris in Brussels Capital region and ADG in the German speaking region. The PES's are accountable to the respective regional governments and hence develop different policies and administrative practices.

The Vlaamse Dienst voor Arbeidsbemiddeling (VDAB) is the PES of the Flanders. VDAB is responsible for registration and placement of jobseekers as well as for vocational training for Flanders and for the Flemish-speaking inhabitants of the Brussels Region. Flanders' PES opted for a comprehensive approach and a guidance model in flexible and multiple stages (preventive for new jobseekers and curative for long term unemployed) with different modules. This approach is aligned to EU Employment Strategy guidelines.

VDAB has central offices, 13 sub-regional local labour market management offices (regionale arbeidsmarktdirectie) and 6 provincial competence centres (provinciaal competentiecentrum). The local sub-regional labour market management offices provide labour market mediation (basic services, such as providing information on vacancies, guidance, multi module labour mediation, services for employers and counselling) and 'labour market direction' (regie). The task of directing the local labour market consists of (1) enhancing collaboration in the (local) labour market, (2) aligning the services of the different labour market actors, (3) stimulating the market and (4) making strategic choices on the basis of local labour market dynamics. The provincial competence centres are the training management platforms of the PES. They manage all tasks related to the development and assessment of competences: management, planning and outsourcing. They run several training centres within each province, provide coordination and cooperation in relation to vocational and other types of training, retraining and in-service training. Jobseekers can follow training courses in the competence centre of their choice. 
Figure 3. VDAB organisational chart

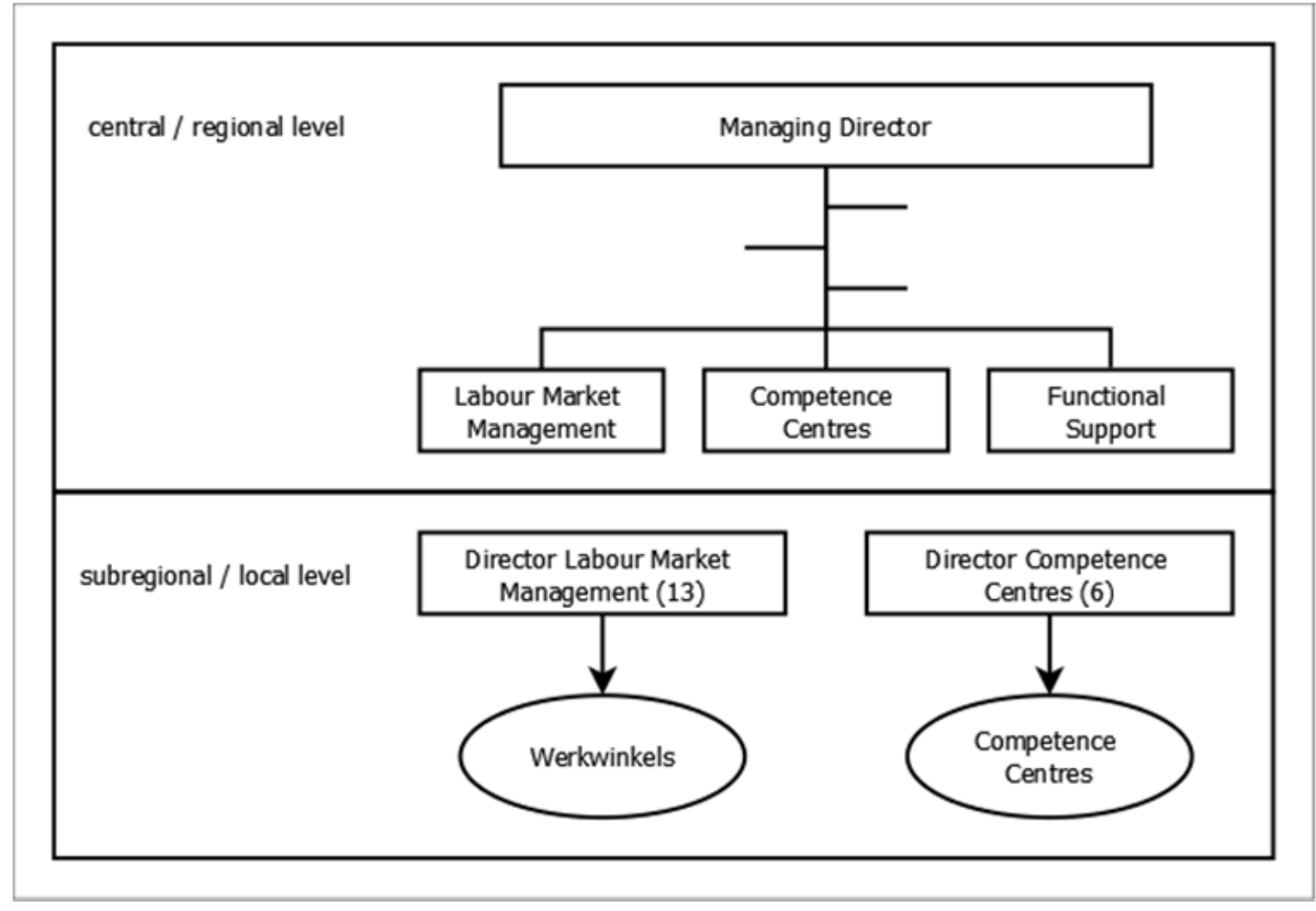

VDAB is currently undergoing an internal reorganisation, called 'provincialisation'. The competence centres are already organised on the provincial level. In the future, in addition to the 13 existing local sub regional labour market offices, the VDAB will also create an intermediate provincial structure with each of the 13 offices belonging to one of the five provincial managements. More information is provided in the section on 'Future Directions' below.

\section{The Federal National Employment Office}

At the federal level, the main focus is on the administration of unemployment benefits. The National Employment Office ('RVA'; NEO) is responsible for unemployment benefits, prevention of unemployment and providing funding for a limited set of programmes to support the re-integration of unemployed people back to the labour market (e.g. ACTIVA ${ }^{2}$ and the service vouchers programme). Administering regular unemployment benefits is the most important assignment of the NEO. The NEO runs several compensation programmes, including compensation for career breaks and the use of time credit. The NEO supports job creation and the use of activation measures at local level through 'local employment agencies' (PWA). The NEO aims to activate the job seeking attitude of the unemployed by face-to-face interviews on a regular basis (called the ‘DISPO’ procedure).

The NEO has 30 local unemployment offices that fulfil the basic assignments of the NEO. This consists of processing the files of the unemployed; deciding on the entitlement to benefits in case of total

\footnotetext{
${ }^{2}$ ACTIVA is an activation measure. This measure reduces the employers social security contributions when hiring a jobseeker and also 'activates' the unemployment or social assistance benefit. This means that they keep a part of their benefit ( $€ 500$ in general, called labour benefit), in addition to their wage. The employer deduces the this labour benefit from the common net wage. So, it further reduces the costs of a new employee. This measure is timelimited.
} 
unemployment, temporary unemployment, early retirement, part-time work, career break and time-credit; inviting the long term unemployed to activation interviews and taking care of the administrative management involved; controlling the payments made by the payment bodies; looking for and taking action against breaches and potential misuses; co-ordinating the Local Employment Agencies (LEAs, or in Flemish 'PWA,' run by municipalities) and, together with the issuing company, following up the service cheques system. These local offices are divisions under the hierarchy of the NEO.

\section{Box 1. The partnership of NEO and PES}

A partnership agreement was signed in April 2004 to strengthen the co-ordinated action of the NEO and the PES. The agreement specified that guidance and monitoring of the unemployed must start at the beginning of unemployment. The agreement also aimed in the longer term to create a 'right to guidance', as well as the duty of the unemployed to actively seek a job and to work together with advisors on all actions that strengthen their labour market chances (RVA, 2009). The agreement also facilitated the data transmission between both partners. As a consequence, the NEO can follow the employment and training actions proposed to the unemployed by the PES.

A partnership agreement was signed in April 2004 to strengthen the co-ordinated action of the NEO and the PES. The agreement specified that guidance and monitoring of the unemployed must start at the beginning of unemployment. The agreement also aimed in the longer term to create a 'right to guidance', as well as the duty of the unemployed to actively seek a job and to work together with advisors on all actions that strengthen their labour market chances (RVA, 2009). The agreement also facilitated the data transmission between both partners. As a consequence, the NEO can follow the employment and training actions proposed to the unemployed by the PES. 


\section{Other actors involved with employment policy at the local level}

At the local level as well, different actors are involved with the local labour market.

- Local authorities: cities and municipalities usually have an alderman responsible for the local economy. Some local authorities also have a local employment department (gemeentelijke/stedelijke tewerkstellingscel). The local authorities act on different matters as 'director' (i.e. they take a lead in coordination) or as an 'actor' (i.e. they are just one of a number of participants).

- The municipalities (or a group of municipalities) constitute the Local Employment Agencies (LEAs). These agencies promote federal employment measures (e.g. ACTIVA) and the service vouchers system to employers and employees or unemployed persons. They also enable long term unemployed to access publically created jobs (called 'PWA-jobs') that cover local service needs not met by the market. Examples of these 'jobs' are gardening and domestic activities for private households, traffic control near schools, help with organising occasional events for municipalities, seasonal labour on farms, etc. The LEAs act as non-profit associations and are embedded in the one-stop job shops ('werkwinkel').

- The OCMW (Public Social Assistance Centre) are a particular kind of local government agency with substantial autonomy. They provide assistance and guidance (including a basic income) to persons with insufficient or no social security rights (roughly $1 \%$ of the Flemish population). OCMW's work to support employment and social inclusion for this group through social workers. Larger OCMW's may have an internal employment department while other OCMW's organise an employment department in cooperation with other OCMWs ('clusters'). The clients of OCMW can have very difficult profiles for labour market integration; in particular because of the multi-dimensionality of the problems they face (drug addiction, indebtedness, etc.).

The OCMWs have a significant local autonomy to implement the federal legislation regarding the 'right on social integration' (RMI, 'recht op maatschappelijke integratie') and 'individual plans on social integration' (GPMI, 'geöndividualiseerd plan voor maatschappelijke integratie'). OCMWs can hence develop their own activation policy, depending on their budget and their policy vision on activation. OCMWs can use federal measures to activate their social assistance clients, but they can also take their own training or employment initiatives. Since the municipality has to cover any deficits created by the OCMW, the financial means for these local initiatives are covered by the local community ${ }^{3}$.

The role of the local authorities

The competences of local authorities in principle are very broad: the Belgian constitution stipulates that they can take initiatives on all matters of local importance. Local governments have to be able to finance their activities and they do not normally receive special financial means for labour market policies, although the 13 central cities receive a special contribution to support their coordination role in relation to the local services economy, and a 'City fund', which finances the additional costs of regional coordination in a broad range of policy areas, not limited to labour market policy. But if local governments wish to, and they can afford it, they can develop their own local labour market policies. Some municipalities have more

\footnotetext{
${ }^{3}$ More information on the activation policy of the OCMW, and the differences towards the approach of the unemployed and the jobseekers on benefits and labour mediation can be found in Bogaerts, Marx, Vandelannoote and Van Mechelen, 2010
} 
ambitions in this field than others. In particular larger cities are eager to take up a role in defining local policies.

Local authorities do have a legal role to operate as coordinator (regie) or as an actor in relation to certain issues on local labour market policy as defined in partnership agreements. The local authorities carry political responsibility in relation to local employment policy and have the task of co-ordinating the work, measures and means of other actors who are involved with labour market policy at the local level. They also hold a specific task as coordinator in relation to the local service economy (lokale diensteneconomie). The local service economy aims at the (re)insertion of disadvantaged groups such as older workers, migrants, long-term unemployed or lower educated persons while also providing services of use to wider society such as additional childcare at neighbourhood level, shopping services, social restaurants, maintaining foot and cycling paths, etc. The local authorities' co-ordinate the overall supply of these different services but can also take the initiative to develop local services themselves.

The local authorities also play an important role in broader employment policies as an actor, within the "local employment policy forum" (see Box 4 for more detail). They must participate in broad partnerships at local and sub-regional level. An analysis of the local situation (quantity and quality) and the needs of local actors and users is a starting point. They also develop indicators and targets on a number of issues related to employment and diversity.

\section{Strategic platforms at regional and sub-regional levels}

Four main actors cover the development of strategic objectives for employment policy at the subregional level. This sub-regional level is not involved in the delivery of active labour market policy for individuals, but rather operates at a strategic level.

A SERR (social-economic counsel of the region - Sociaal-Economische Raad van de Regio) consists of 8 representatives of organisations of employers, SMEs and agriculture and 8 representatives of employee organisations (trade unions). The members of the SERR are appointed by the SERV (socialeconomic counsel for Flanders - Sociaal Economische Raad Vlaanderen). The task of the SERR is (1) to formulate advice on economic and employment policy to the different governments and local authorities and (2) to organise consultation on socio-economic matters of their region.

A RESOC (regional economic and social counsel of the region - Regionaal Economisch en Sociaal OverlegComite) is composed of the 16 members of the SERR and at least 8 representatives of cities, communities and provinces of the specific region. The task of the RESOC is (1) to formulate advice on socio-economic matters to the different governments and local authorities and (2) to elaborate a regional plan (streekpact). This regional plan formulates the joint point of view of local authorities and social partners on regional socio-economic development for the next 6 years.

The ERSVs (acknowledged regional cooperation - Erkend Regionaal Samenwerkings-Verband) are non-profit organisations accredited by the Flemish government. Their task is to organise and support the provincial consultation on socio-economic themes of the representatives of employers and employees of one or more SERRs, as well as of social partners and local authorities (cities, communities and provinces) located in one or more RESOC territories.

On top of these three actors, the Platform socio-economic regional development policy (Platform socio-economisch streekontwikkelingsbeleid) supports and co-ordinates the socio-economic regional planning and the ERSV. They also stimulate the exchange of experiences and best practices between the different ERSVs, SERRs and RESOCs. 
Flanders is divided in 5 ERSV territories (identical to the provinces), 13 SERRs and 15 RESOCs. The ERSVs are financed by the Flemish government, which provides a subsidy to support the staffing and operations of the SERRs and RESOCs. SERR and RESOC hold a common secretariat with the following staff: one coordinator, one staff member, one secretary and two and a half project developers for diversity plans. The provinces can provide additional financing. SERR and RESOC work to find additional funding through European projects, partly for the achievement of their core tasks. Recent Flemish government cuts, however, have also impacted on SERR and RESOC financing. 
Table 3. Territories of ERSV, SERR and RESOC

\begin{tabular}{|c|c|c|c|}
\hline Provinces & ERSV & SERR & RESOC \\
\hline \multirow[t]{6}{*}{ West-Vlaanderen } & 1 & 4 & 5 \\
\hline & & Zuid West-Vlaanderen & Zuid West-Vlaanderen \\
\hline & & Brugge & Brugge \\
\hline & & Oostende-Westhoek & Oostende \\
\hline & & & Westhoek \\
\hline & & Midden West-Vlaanderen & Midden West-Vlaanderen \\
\hline \multirow[t]{5}{*}{ Oost-Vlaanderen } & 1 & 4 & 4 \\
\hline & & Zuid Oost-Vlaanderen & Zuid Oost-Vlaanderen \\
\hline & & Gent en rondom Gent & Gent en rondom Gent \\
\hline & & $\begin{array}{l}\text { Meetjesland, Leie \& } \\
\text { Schelde }\end{array}$ & Meetjesland, Leie \& Schelde \\
\hline & & Waas en Dender & Waas en Dender \\
\hline \multirow[t]{4}{*}{ Antwerpen } & 1 & 3 & 3 \\
\hline & & Antwerpen & Antwerpen \\
\hline & & Mechelen & Mechelen \\
\hline & & Kempen & Kempen \\
\hline \multirow[t]{2}{*}{ Limburg * } & 1 & 1 & 1 \\
\hline & & Limburg & Limburg \\
\hline \multirow[t]{3}{*}{ Vlaams-Brabant } & 1 & 1 & 2 \\
\hline & & Vlaams-Brabant & Halle-Vilvoorde \\
\hline & & & Leuven \\
\hline
\end{tabular}

Source: VVP electronisch handboek provinciaal beleid - socio-economische streekontwikkeling

* Limburg and Vlaams Brabant work with 'regional tables' 


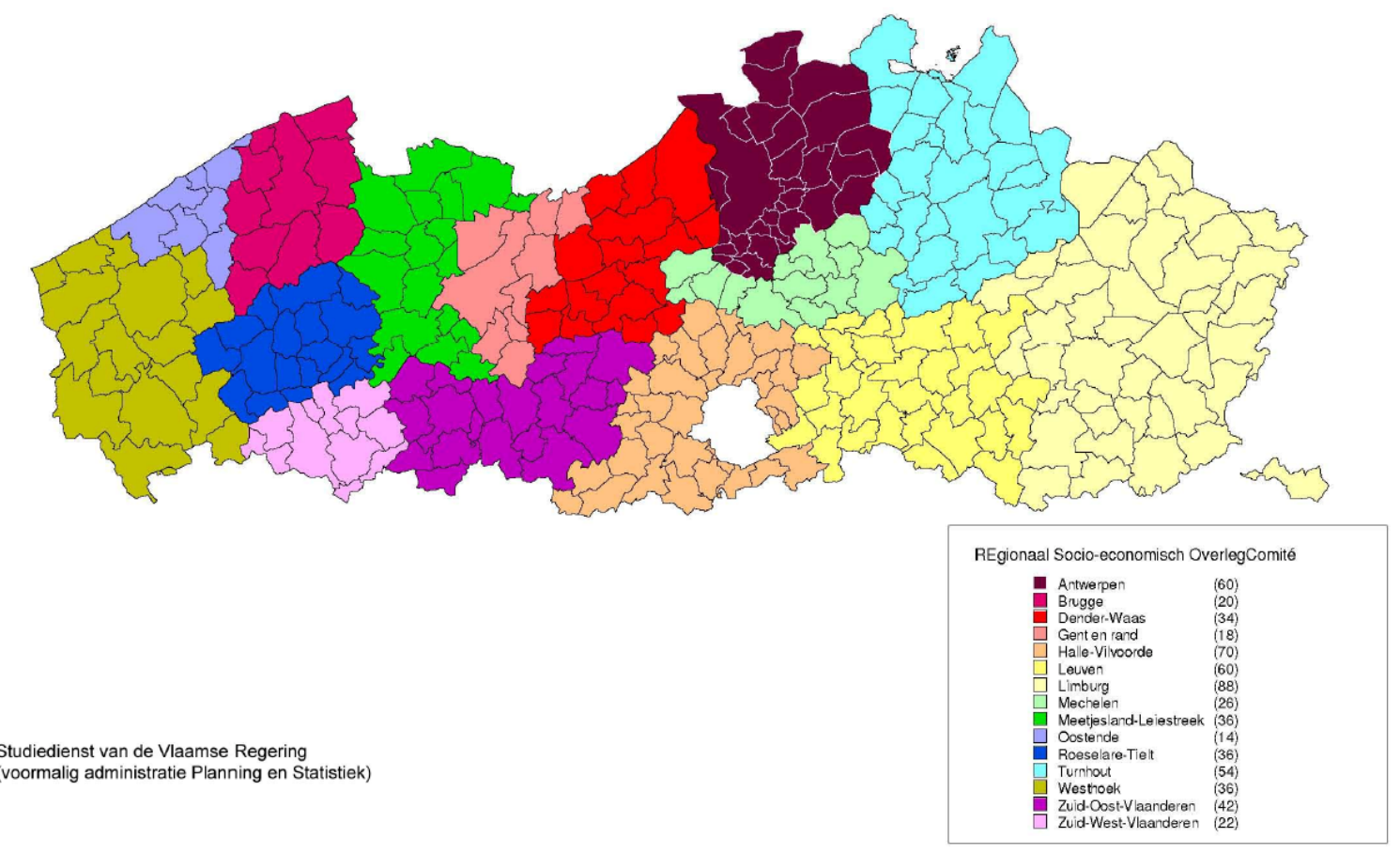

Figure 5. SERR territories
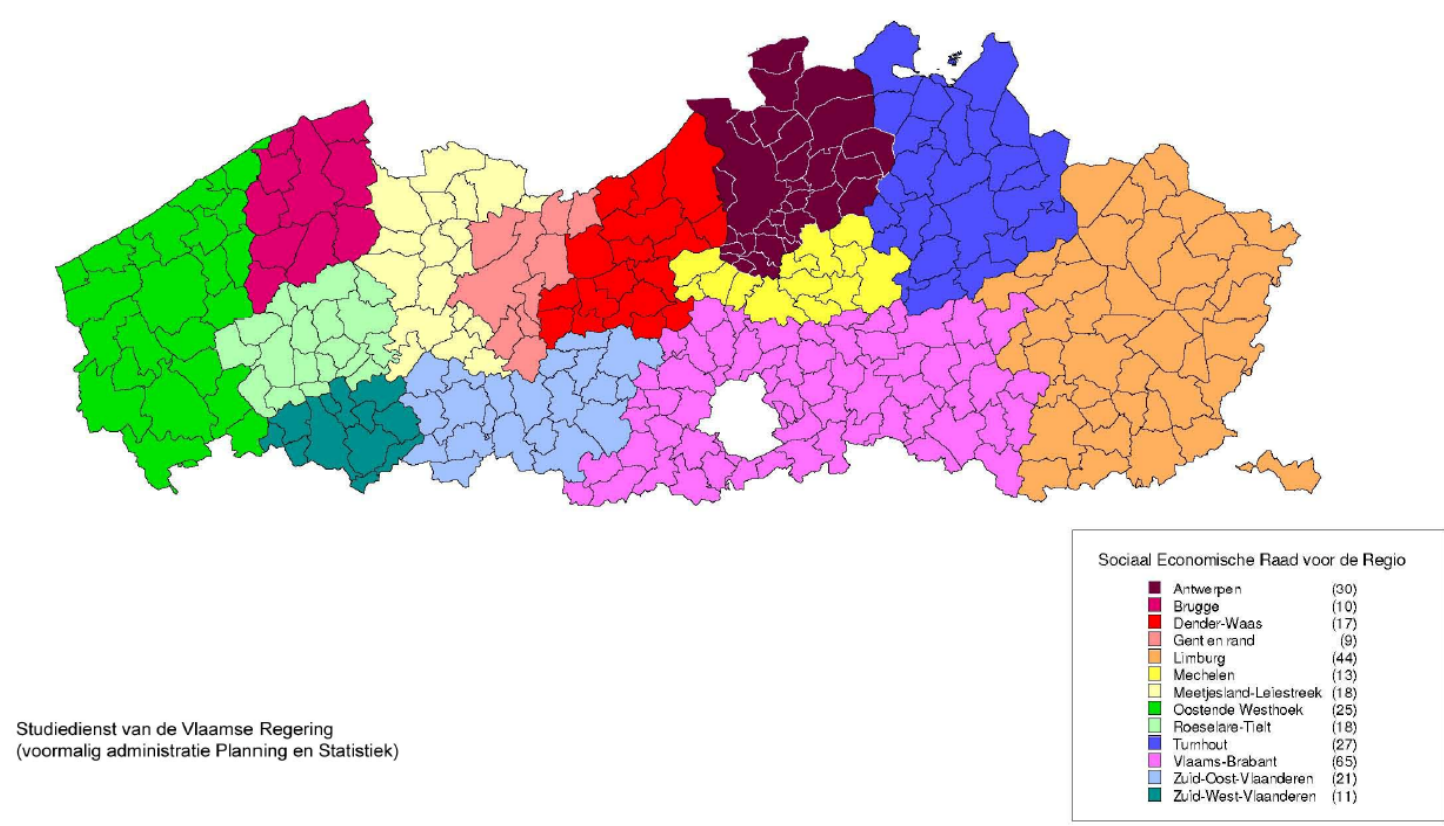

The RESOC has a role in tackling local policy issues such as addressing skills shortages ('bottleneck vacancies'), aligning education and labour market policies and the sub-regional mobility of workers. They do not provide services themselves, but act as a 'strategic coordinator' in their geographical area. They are 
a supporting and advisory body to remedy labour market bottlenecks that businesses are confronted with. In formulating their advice, they are expected to refer to their knowledge of disadvantaged groups and of the local labour market (De Cuyper, Lamberts and Struyven, 2008).

SERR and RESOC have a mandatory role in formulating specific advice on the demand of a Flemish minister, or on the demand of a local or provincial authority in their territory. They can also provide advice on their own initiative. The SERR's are expected to advise on: the VDAB yearly action plan (JAP), mediation (Ombudsman services) for the unemployed, vocational training and on-the-job programmes, the VDAB local project programmes, and diversity plans. The RESOC are expected to advise on start up centres for the social economy, insertion companies, sheltered workplaces, the local werkwinkels, WEP work experience projects and other aspects of the local service economy. Table 2 gives a brief overview on the issues where advice of SERR or RESOC is required.

Table 4. Advisory tasks of SERR and RESOC

\begin{tabular}{|c|c|c|}
\hline Advice area & Main advisor & Other advisors \\
\hline VDAB yearly action plan & SERR & \\
\hline Ombudsman for the unemployed & SERR & Complaints department VDAB \\
\hline $\begin{array}{l}\text { Working by means of vocational } \\
\text { training }\end{array}$ & SERR & \\
\hline IBO (On the job training program) & SERR & \\
\hline VDAB Local Project Programme & SERR & \\
\hline Bureau free labour mediation & SERR & \\
\hline Diversity plans & SERR & \\
\hline $\begin{array}{l}\text { Start up centres for the social } \\
\text { economy }\end{array}$ & RESOC & $\begin{array}{l}\text { Advisory commission on } \\
\text { insertion }\end{array}$ \\
\hline Insertion companies & RESOC & $\begin{array}{l}\text { Advisory commission on } \\
\text { insertion }\end{array}$ \\
\hline Sheltered workplaces & RESOC & $\begin{array}{l}\text { Commission for recognition } \\
\text { on social economy or Forum local } \\
\text { labour market policy }\end{array}$ \\
\hline Local ‘werkwinkels’ & RESOC & \\
\hline $\begin{array}{l}\text { WEP-plus ( work experience } \\
\text { projects) }\end{array}$ & RESOC & VDAB \\
\hline $\begin{array}{l}\text { Art } 107 \text { decreet leren en werken, } \\
\text { deeltijds leren \& werken (decree on part- } \\
\text { time work and study) }\end{array}$ & RESOC & \\
\hline
\end{tabular}

Source : Flemish government, https://www.werk.be/beleid/subregionaal/?SMSESSION=NO (January $10^{\text {th }}$ 2011)

Another task of SERR is to work with enterprises to introduce "diversity plans" (diversiteitsplannen) to support the diversification of their workforce. The SERR project managers help employers and their human resource managers to elaborate these plans. The diversity plans are conceived as a flexible instrument to stimulate diversity themes in HRM and to enhance the employment chances of disadvantaged groups. The types of actions defined in the plans can take different forms such as: the use of 
alternative channels for recruitment, a welcome brochure for new employees, job coaching, on-the-jobtraining. Enterprises receive a subsidy for the development of these diversity plans. SERR receives goals regarding the yearly number of diversity plans they have to help draw up.

The RESOC regional planning document 'streekpact' must contain the following issues: (1) an analysis of the socio-economic development in the region, with special interest towards vulnerable groups on the labour market; (2) a long term strategy for socio-economic development which keeps in mind the balance between economy, employment and attention to mobility, environment, welfare and education; (3) the commitments of the different members of the council; (4) the goal attainment measurement; and (5) the procedure to involve local authorities. The local authorities must all ratify this regional planning document.

The RESOC itself receives no core funding for policy measures designed within the 'streekpact'. It is expected that the partners engaged in the RESOC will integrate the actions within their mainstream provision. RESOC's can however attempt to attract means to finance their own initiatives. Usually, this comes in the form of project subsidies from the Flemish government, provinces (and POM - Provincial Development Agency), the European Social Fund or European Regional Development Funds. Not all RESOC's seek own resources. This leads to substantial differences in the capacities and actions of the different RESOCs.

The advice of SERR and RESOC to higher and lower tier governments on issues concerning the local labour market, as well as the RESOC regional plan, holds the potential to influence decision making at different tiers of government. However, it is not clear to what extent this local or sub-regional input is used in central decision making. Several respondents doubted whether these planning documents -streekpactenare used at all. A formal mechanism or obligation to incorporate this material or advice in central policy is not provided. The content and focus of the regional planning document can be freely determined by RESOC, as well as the actions that arise from the planning. Arguably, the intensity of use of the planning document will differ from RESOC to RESOC, depending on local institutional and political circumstances. 


\section{Box 2. Key issues in the regional planning document of RESOC Mechelen}

For the period 2007-2013, the regional planning document for region Mechelen introduced a range of key themes for their region.

1. General SERR and RESOC issues: building and strengthening networks; working together on institutional mapping, statistics, communication and the development of a shared viewpoint.

2. Mobility within the region: the Mechelen region, which is a central region, has to deal with a large amount of traffic congestion. This analysis has resulted in the project 'Move forward together', to lobby at higher government level on infrastructural priorities for the region.

3. Alignment education and labour market: the region faces some specific skill shortages such as welding and care workers. This results in two projects: (1) the construction of a welding training centre in the region, organised by RESOC, with European Structural Funds and in dialogue with VDAB and private partners, and (2) in an effort to solve the shortage in care workers, RESOC is encouraging young people towards relevant educational trajectories (project: 'Unknown, unloved').

4. Local service economy: the city of Mechelen has the resources and staff to work on social economy issues, but smaller municipalities do not always have this capacity. The RESOC works on enhancing local service economy in smaller municipalities by supporting coordination and networking.

5. Diversity is a very important subject for RESOC and encompasses different types of actions, including implementing the diversity plans. The RESOC has also funded complementary research on this theme with ESF funding, focusing on the development of 'balanced careers' over the lifecycle, taking into account the age and competences of employees. 


\section{ANALYSING THE FLEXIBILITY WITHIN THE FLEMISH SYSTEM}

\section{Methodology: Description of the survey, interviews and round tables}

A key task for this OECD study was to identify the management flexibility available to the Flemish Public Employment Service (VDAB) and understand how this has enabled the PES to collaborate with other local actors and to link its programmes and policies into broader employment and economic development strategies. In order to achieve this, research included an electronic survey which was distributed covering the main research questions, designed and provided by the OECD LEED Programme, to four types of organisations. All organisations in the below categories received an invitation to fill the survey.

The following organisations received the e-questionnaire ${ }^{4}$.

- $\quad$ The regional VDAB offices (directie arbeidsmarktbeheer) (13). Of these, 10 responded.

- $\quad$ SERR (13) and RESOC (15). Of these, 8 responded.

- $\quad$ Provinciaal competentiecentrum (5). Of these 4 responded.

The desk research and the electronic survey was complemented by interviews with the representatives of key organisations involved in local labour market policy (see the list of interviewees in Annex 2 to this report) following an OECD discussion framework. In these interviews, different key issues on flexibility and accountability of local labour policy were discussed. Finally, three round tables were organised as part of the OECD study tour. Two of these roundtables were in selected case study areas: the City of Antwerp and the Kortrijk region. The third round table brought together a range of representatives of central organisations. Detailed lists of the participants can also be found in Annex 2. The study findings follow below.

\section{Programme strategy, goals and design}

\section{Regional and Federal programmes}

Employment and activation measures are designed and financed mainly by federal and regional governments in Belgium. For example both the NEO and the VDAB (PES) define the specifications of the measures, their outcome and the juridical and fiscal implications of participation at central level. The Flanders and Belgian governments also provide administrative facilities and central financing. Within this framework, local NEO/RVA, VDAB and PSAC OCMW offices (whether or not within the framework of the one-stop local job shop 'werkwinkel') manage access to employment or activation measures for individual clients. They can use measures and instruments at their own discretion to i) guide individual

\footnotetext{
${ }^{4}$ As the SERR and RESOC's are co-ordinated by the same persons, the survey was filled once for both organisation, despite the fact that the SERR and RESOC do not always cover the same sub region. Response to the questionnaire was 10 out of 13 local PES offices, 7 out of 13/15 SERR and RESOC and 4 out of 5 provincial competence centres.
} 
clients at the local level, ii) meet local labour market needs in terms of filling skills shortage vacancies and training needs within the central framework formulated by the management board of VDAB. The VDAB is not obliged to implement all the possible programmes designed centrally, but can pick those most relevant to the local labour market. This means that they can insert local 'accents' in the implementation of the measures within the central targets and the global framework.

The 13 sub-regional offices of the VDAB PES are also given the possibility to design additional measures or actions to meet specific local needs, by means of the 'Local Project Programme' (LPP). The amount of this budget depends of different regional characteristics (see Chart 5) but it is a relatively small part of the overall budget pot. A significant part of this yearly budget is pre-allocated for the continuation of ongoing projects which deliver good results. These projects also have a sub-regional origin and can be very diverse in nature (training, counselling, in service guidance). It was pointed that at least some of these projects could be mainstreamed into normal PES delivery, as opposed to taking up part of a budget which is allocated for new and emerging local needs. Apart from the Local Project Programme, VDAB also mentions the ability of Provincial Competency Management to introduce additional training initiatives as a source of flexibility. These training courses can be provided to meet needs not covered by regional or federal policies or to complement existing programmes. They can be outsourced to other training partners if necessary.

Respondents to the OECD e-questionnaire found that flexibility in programme design was perceived as moderate to high by most respondents. However, most actors indicated that more flexibility was required to elaborate labour market programs adapted to local needs.

Chart 2. Perceived flexibility in programme design

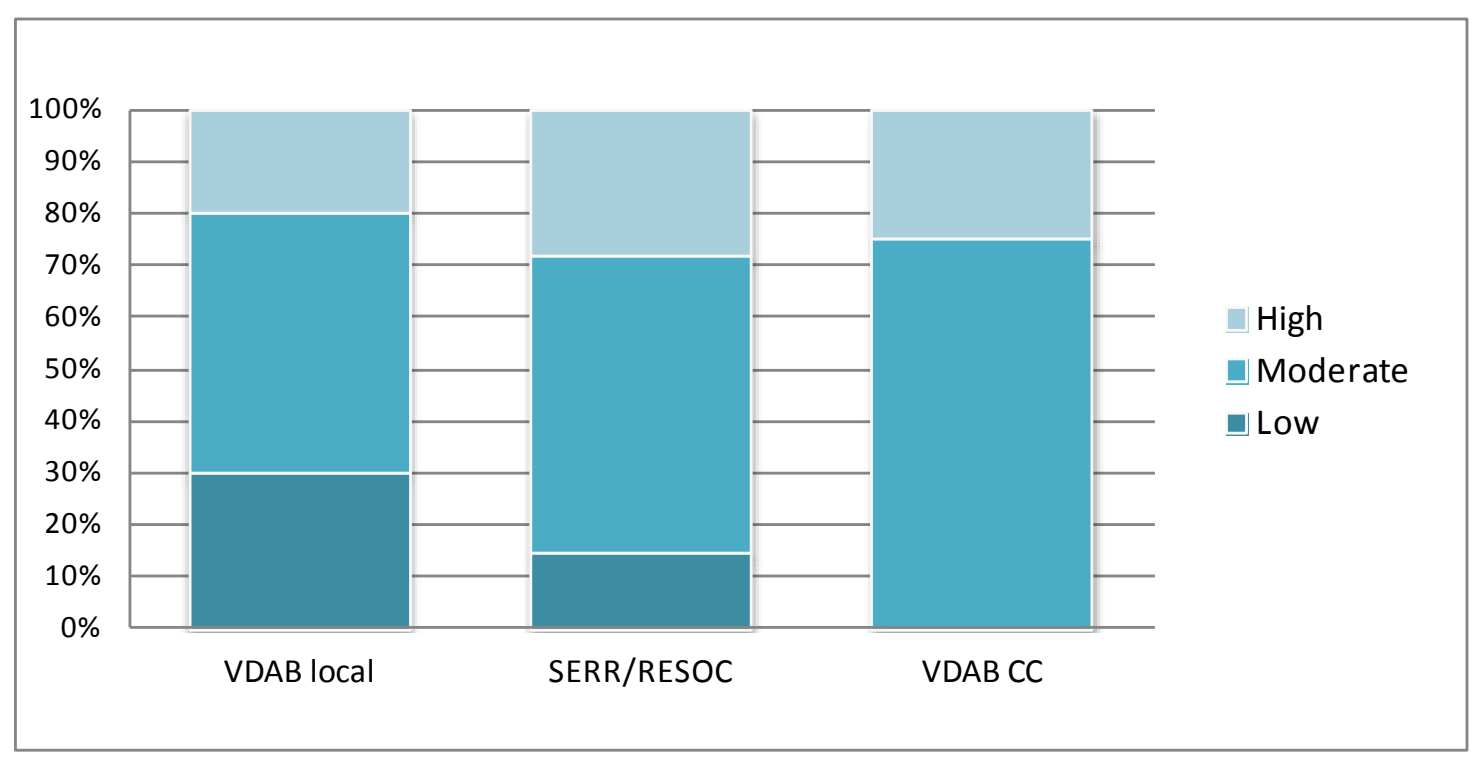

Source: OECD Managing Accountability and Flexibility e-questionnaire.

\section{Flexibility available to other local actors}

As identified above, local governments can develop an employment department, together with their alderman for economy and/or employment. Within this framework and as defined in agreements, the local governments can elaborate own initiatives for the local labour market. Participants of the round tables widely share the perception that large cities such as Antwerp and Ghent and regional capitals such as Kortrijk, Mechelen or Hasselt hold more local governance capacity and means than the smaller 
municipalities for developing labour market policy. Therefore, local variety in the scope of structures and actions emerges. On one end of the spectrum, mostly in small municipalities, the alderman for work or employment participates in different platforms or counsels and defends local interests. At the other end of the spectrum, a complete infrastructure is elaborated to support labour market policy, with staff elaborating a local employment policy plan, accomplished in partnership with other local, sub-regional or sectoral organisations. This can only be achieved in large cities such as Ghent and Antwerp. There is disagreement as to how much capacity there is within other municipalities to effectively get involved in labour market policy. The VDAB only finds that this capacity exists in Antwerp and Ghent, others would also include regional cities of around 50000 to 90000 inhabitants or work with urban regions (“stadsregio's”).

\section{Eligibility}

Both the NEO and the VDAB define their target groups and eligibility criteria for their programmes centrally. Most survey respondents said that there were groups that they found it difficult to work with. Examples include persons with language problems (due to immigration and/or problems with literacy and numeracy), people who have poor educational attainment, older workers (over 50 years of age), persons with health restrictions (physical and mental) or persons who are confronted with a combination of such factors. There is considerable regional differentiation in the types of people who have trouble in integrating into the labour market. Ghent, for example, is confronted with a large inflow of immigrants from countries such as Romania and Bulgaria, who can sometimes experience challenges in the labour market, whereas these groups are not so present in other labour market areas.

Respondents from the VDAB identified that they are forced to turn away only a small number of people when they seek assistance, most of whom they refer to other agencies. However federally and regionally designed measures were considered by several actors to insufficiently cover local disadvantaged groups. The Work and Investment Plan (WIP), for example, includes funding for specific initiatives for older workers in the context of the economic crisis. Antwerp, however, is confronted with a problem of youth unemployment (reinforced by the crisis), but the additional means provided through the WIP cannot be used to remedy this problem. Some local stakeholders (for example in Antwerp) found the eligibility criteria established within VDAB training schemes were also too rigid, which meant that they were not broadly accessible to local disadvantaged groups. They also cited the lack of measures to cover barriers to employment such as home-to-work mobility and a lack of affordable and flexible childcare. Local actors argue that they are in the best position to identify such barriers to employment, since they have the best understanding of how different barriers play out in a local context. The city of Antwerp is seeking to address labour market disadvantage more holistically by integrating policies which address educational, economic and labour issues.

\section{Targets and performance measures}

Sub-regional VDAB PES offices, VDAB provincial competence centres and SERR/RESOC work with performance targets set at the central level, although the survey respondents indicated a certain degree of negotiation exists. 
Chart 3. Presence of negotiation on the organisations targets.

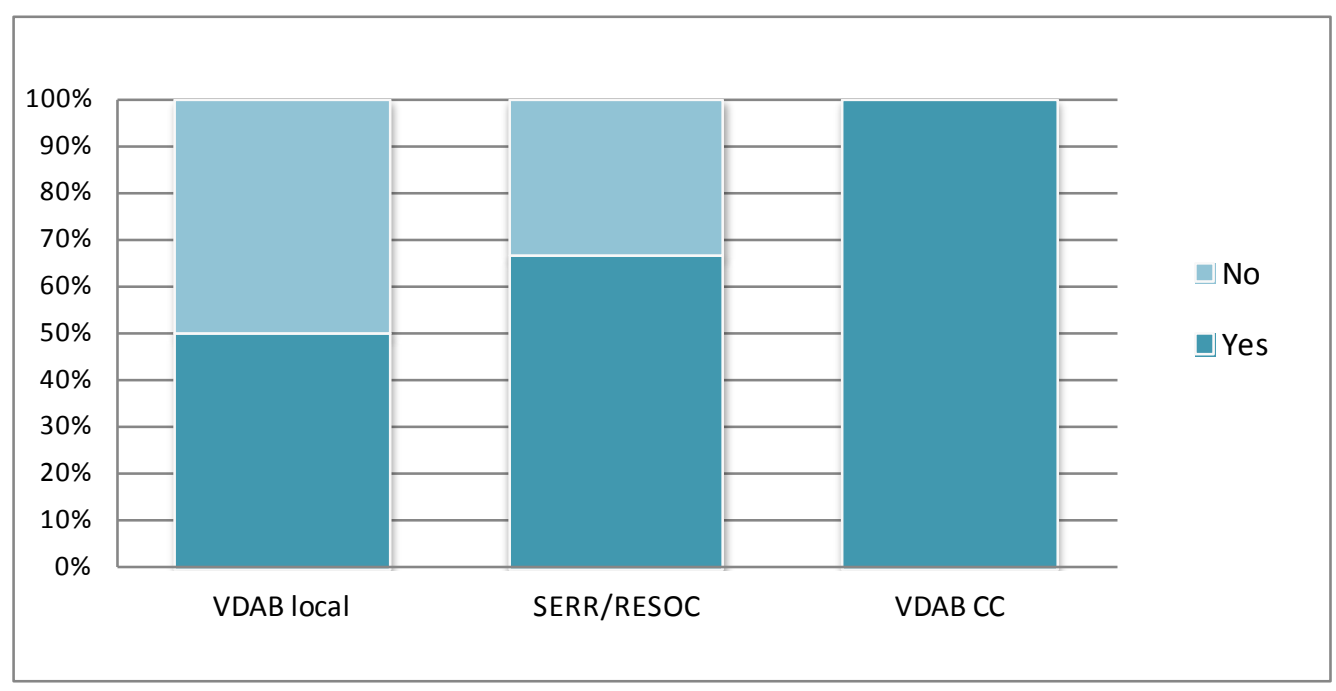

Source: OECD Managing Accountability and Flexibility e-questionnaire.

The targets of the sub-regional VDAB directions are based on the targets defined in the management agreement of the PES with the Flemish government and the yearly business plan ('JOP') of VDAB at central level. These targets are translated to the sub-regional offices. This also counts for the provincial competence centres with targets on number of training hours, number of participants and customer satisfaction. Decisions on sub-regional targets are made by a board of directors in which sub-regional VDAB directors are represented (rotation system). The new agreement for the period 2011-2015 contains the following (new) priorities.

- A tailor-made activation trajectory for all jobseekers and other non-active citizens in order to achieve a sustainable insertion in the labour market;

- $\quad$ Career services for employees;

- $\quad$ Tailor-made service for employers;

- Organise a future-proof supply for recognising and developing competences;

- An expansion of existing partnerships.

In addition, the agreement between the PES and the Flanders government also focuses on improvements to the internal functioning of the organisation, the development of a performance budget and on staff diversity. Although previous management agreements also defined process objectives, the new agreement is based entirely on outcome targets, in addition to customer satisfaction measurements. Qualitative evaluation reports are also sought for areas of performance which are difficult to capture in targets or are in experimental phase. The new agreement of the PES (and the social partner represented in the management board) with the Flemish government has fewer indicators and provides more leeway and flexibility (see Future Directions). 
Table 5. Targets and objectives as agreed in the 2011-2015 VDAB management agreement.

\begin{tabular}{|c|c|c|}
\hline & $\begin{array}{c}\text { Type of } \\
\text { measurement }\end{array}$ & Objective \\
\hline \multicolumn{3}{|c|}{$\begin{array}{l}\text { Strategic target 1: a tailor made activation of all jobseekers and other non-active persons citizens in order to } \\
\text { achieve a sustainable insertion in the labour market }\end{array}$} \\
\hline$\bullet \quad$ Target parameter 1: satisfaction of the jobseekers & Satisfaction & $75,0 \%$ \\
\hline \multicolumn{3}{|l|}{$\begin{array}{l}\text { Operational target } 1 \text { : tailor made approach of mediation and } \\
\text { counselling for new jobseekers }<25 \text { years }\end{array}$} \\
\hline $\begin{array}{l}\text { - Target parameter 2: outflow jobseekers }<25 \text { years towards } \\
\text { work }\end{array}$ & Result & $57,0 \%$ \\
\hline \multicolumn{3}{|l|}{$\begin{array}{l}\text { Operational target } 2 \text { : tailor made approach of mediation and } \\
\text { counselling for new jobseekers } 25-50 \text { years }\end{array}$} \\
\hline $\begin{array}{l}\text { - Target parameter 3: outflow jobseekers 25-50 years towards } \\
\text { work }\end{array}$ & Result & $47,5 \%$ \\
\hline \multicolumn{3}{|l|}{$\begin{array}{l}\text { Operational target 3: systematic approach for new jobseekers }>50 \\
\text { years }\end{array}$} \\
\hline $\begin{array}{l}\text { - Target parameter 4: outflow jobseekers }>50 \text { years towards } \\
\text { work }\end{array}$ & Result & $30,0 \%$ \\
\hline \multicolumn{3}{|c|}{$\begin{array}{l}\text { Operational target } 4 \text { : gradually faster activation mid and long term jobseekers by using a } \\
\text { suitable approach }\end{array}$} \\
\hline $\begin{array}{l}\text { - Target parameter 5: outflow jobseekers longer than year } \\
\text { without work towards work }\end{array}$ & Result & $11,5 \%$ \\
\hline \multicolumn{3}{|l|}{ Operational target 5: maximal activation of disadvantaged groups } \\
\hline $\begin{array}{l}\text { - Target parameter 6: outflow jobseekers from disadvantaged } \\
\text { groups towards work }\end{array}$ & Result & $18,0 \%$ \\
\hline \multicolumn{3}{|l|}{$\begin{array}{l}\text { Operational target 6: address a specific approach to groups vulnerable } \\
\text { for the labour market (poor, persons with mental, medical, psychical } \\
\text { and psychological problems, lone parents, re-entrants, ...) }\end{array}$} \\
\hline - No target parameter & Evaluation report & \\
\hline \multicolumn{3}{|l|}{$\begin{array}{l}\text { Operational target } 7 \text { : improve cooperation between Flemish actors on } \\
\text { restructuring policy }\end{array}$} \\
\hline $\begin{array}{l}\text { - Target parameter 7: outflow jobseekers after restructuring } \\
\text { towards work }\end{array}$ & Result & $41 \%$ \\
\hline \multicolumn{3}{|l|}{ Strategic target 2: Career services for employees } \\
\hline \multicolumn{3}{|l|}{$\begin{array}{l}\text { Operational target 8: provide quality information about career related } \\
\text { issues (fazed introduction of basic services for employees in the } \\
\text { 'werkwinkel') }\end{array}$} \\
\hline - Target parameter 8: satisfaction of the employees & Satisfaction & $85,0 \%$ \\
\hline \multicolumn{3}{|l|}{$\begin{array}{l}\text { Operational target 9: provide career counselling, especially for } \\
\text { disadvantaged groups }\end{array}$} \\
\hline - No target parameter & Evaluation report & \\
\hline \multicolumn{3}{|l|}{$\begin{array}{l}\text { Operational target 10: introduce a digital portfolio 'my career' from } \\
\text { labour market direction point of view }\end{array}$} \\
\hline $\begin{array}{l}\text { - Target parameter } 9 \text { : satisfaction on the digital portfolio 'my } \\
\text { career' }\end{array}$ & Satisfaction & I \\
\hline \multicolumn{3}{|l|}{ Strategic target 3: tailor made services for employers } \\
\hline \multicolumn{3}{|l|}{$\begin{array}{l}\text { Operational target 11: provide quality information about labour market } \\
\text { related issues to employers }\end{array}$} \\
\hline - Target parameter 10: satisfaction of the employers & Satisfaction & $75,0 \%$ \\
\hline \multicolumn{3}{|l|}{$\begin{array}{l}\text { Operational target 12: provide tailor made, quality and customer } \\
\text { friendly support in order to fill vacancies, special attention to SME's }\end{array}$} \\
\hline $\begin{array}{l}\text { - Target parameter 10bis: satisfaction of the employers on } \\
\text { vacancy services }\end{array}$ & Satisfaction & $63,5 \%$ \\
\hline $\begin{array}{l}\text { - Target parameter 10ter: satisfaction of the SME's on vacancy } \\
\text { services }\end{array}$ & Satisfaction & $63,5 \%$ \\
\hline
\end{tabular}




\section{Strategic target 4: A future proof supply for recognising and developing competences}

- Target parameter 11: satisfaction of the course members

Satisfaction

$80,0 \%$

Operational target 13: facilitate labour market transitions by offering possibilities for competence enhancement

- Target parameter 12: outflow after competence enhancement

Result towards work

- Target parameter 13: reach of the comptence centres actions

Result

50,000 persons and

$12,000,000$

hours

Operational target 14: recognise competences

- No target parameter

Evaluation report

Operational target 15: enhance the flexibility of the supply of training, related to labour market demand

- No target parameter

Evaluation report

Operational target 16: efficient enhancement of competences and investment in on the job actions

- $\quad$ Target parameter 14: reach of the competency enhancing actions on the job actions

- $\quad$ Target parameter 15: reach of e-learning

Result

Result

Evaluation report

Satisfaction

Evaluation report

Evaluation report

Evaluation report

Source: management agreement of the Flemish government and the VDAB 2011-2015.

The follow-up or monitoring of these diverse targets at the sub-regional and provincial level is carried out on a monthly basis by the central VDAB office using central benchmarking. With this monthly followup, VDAB aims to keep track of progress and anticipate problems in reaching targets. The use of the scorecards is said to allow for dialogue in explaining why particular targets are not reached. It is important for the sub-regional level to provide sensible motivations for their (non-)compliance with the targets. However the management of VDAB does not see the performance management framework as a sanctioning tool. There are no financial implications for sub-regional directions who do not meet their targets. Instead, performance information is understood to feed into a learning culture (Van Dooren, Bouckaert \& Halligan, 2010; Van Dooren \& Van de Walle 2008).

All assignments of SERR and RESOC are defined in the Flemish Decree (2004) on Socio-economic sub-regional Consultation. In general, these tasks consist of organising consultation on socio-economic matters and formulating advice. Every SERR also receives specific targets on the number of diversity plans they have to develop on a yearly basis within their region, and every RESOC is obliged to elaborate a regional planning document. SERR and RESOC can freely interpret how to carry out these tasks. In some 
sub-regions the SERR and RESOC limit their tasks to what is provided by the decree, but most of them go beyond the decree.

The activities of SERR and RESOC must be described in a report containing both financial prospects as well as a plan for the following year. SERR/RESOC co-ordinators indicate that this annual planning document itself is merely a formal requirement, as almost no specific and measurable targets are defined. The Flemish government has the possibility to cut the personnel and means of SERR and RESOC, but no precedent of this exists. The Flemish government confirms that there is no mechanism for monitoring for SERR and RESOC. RESOC co-ordinators indicate that the evaluation of whether or not the SERR and RESOC meet their targets lies solely with the RESOC and SERR boards.

Not all the activities of the VDAB, RESOC and SERR are subjected to external evaluation. Most local actors in the field of labour market policy define, often in cooperation with other actors involved, their own additional targets. These can include: regional interpretations of centrally allocated targets, targets for specific local projects, the elaboration of priorities based on the regional planning document and targets in relation to customer satisfaction. Space for defining joint main targets is non-existent. In the agreements of the VDAB with the cities of Antwerp or Ghent, for example, every actor sticks to their own targets.

The paperwork the sub-regional actors and local governments face in order to justify their activities is perceived to be high (although local governments do not have to meet central targets in relation to their work on employment). The actors remark that the formal tasks of the organisation may sometimes only be covered or designed in a certain direction in order to meet formal targets as opposed to in response to local needs. For example jobseekers are placed in training initiatives in order to reach the required number of training hours, diversity plans are developed using a predefined format that does not entirely fit the enterprise. Local actors often see this paperwork as evidencing a lack of confidence from central governments or administrations in the sub-regional or local organisations.

\section{Budget and finances}

At central level, VDAB is mainly financed by subsidies from the Flemish government. These subsidies are linked to the VDAB's management agreement and associated targets. The subsidies are complimented by European subsidies, funds from the federal Insertion Plan and the receipts of partner contributions within one-stop shops (i.e. training delivered for a fee, employer contributions within the onthe-job IBO vocational training programme and the reimbursement of work subsidies for older workers). The VDAB at central level finances the services and premiums for jobseekers, tenders and outsourcing, the operational costs and staffing at the central and sub-regional level. The sub-regional VDAB directions and provincial competence centres must operate within this framework. The sub-regional VDAB directions mention that they have a certain degree of freedom in spending their budget by flexibly engaging their staff members as long as the general personnel framework and the VDAB mission are respected. This is however not always easy, as the number of personnel (in FTE) depends on several parameters, for example the number of jobseekers. In the Kortrijk region, with only a limited number of jobseekers, the VDAB only receives restricted resources which leaves a limited scope for new projects and the coverage of local problems such as restricted home-to-work mobility in the region.

In general, the financial means of the local and sub-regional bodies are earmarked and it is not possible to move funding between budget lines. In addition, the central offices of VDAB provide most of the central financing, trainings and benefits. Hence budget flexibility seems to be virtually absent. On the other hand, as the VDAB provincial and sub-regional level is responsible for implementing the basic and additional services without responsibility for the distribution of resources on different measures and actions, budget flexibility is not always deemed necessary. If it is decided centrally to launch a tender to 
meet local needs (as opposed to the tender being launched bottom up), then this can bring additional local budgets. The VDAB also emphasises the importance of partnerships at the local level. Local organisations with their own resources can be brought together to create additional local flexibility.

In most cases, budgetary constraints on the number of participants which can take up programmes at central or local level are non-existent (except in the case of some measures such as social economy, local services economy, sheltered workplaces and some activation measures managed by the PSACOCMW where only a limited number of initiatives and workplaces are subsidised).

Chart 4. The perception of flexibility in budget management

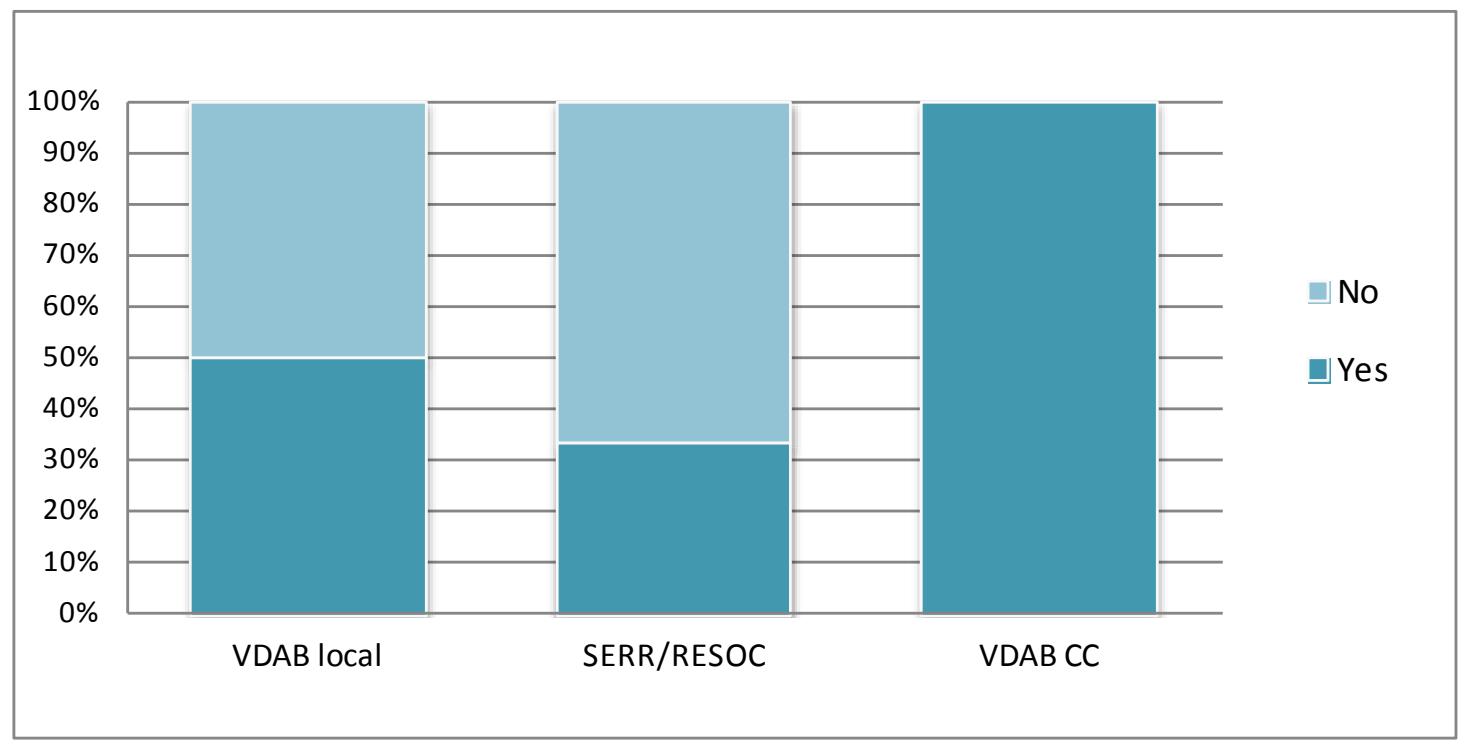

The means for the 'local project programme' (LPP) add some flexibility to spend on local initiatives, but this budget is limited. Given the varying capacity of different sub-regions, the following graph on the LPP budget at sub-regional or provincial level shows a large regional diversity on the amount the subregions can spend on these issues. The distribution of the total yearly LPP budget of €2,365,000 (2010 budget) is determined by local labour market and jobseeker characteristics. Some queried the criteria used as sub-regions with a large city receive a larger share. Low unemployment areas, such as Kortrijk, receive a smaller share that, in their opinion, cannot cover the local problems they face to activate the remaining share of jobseekers. 


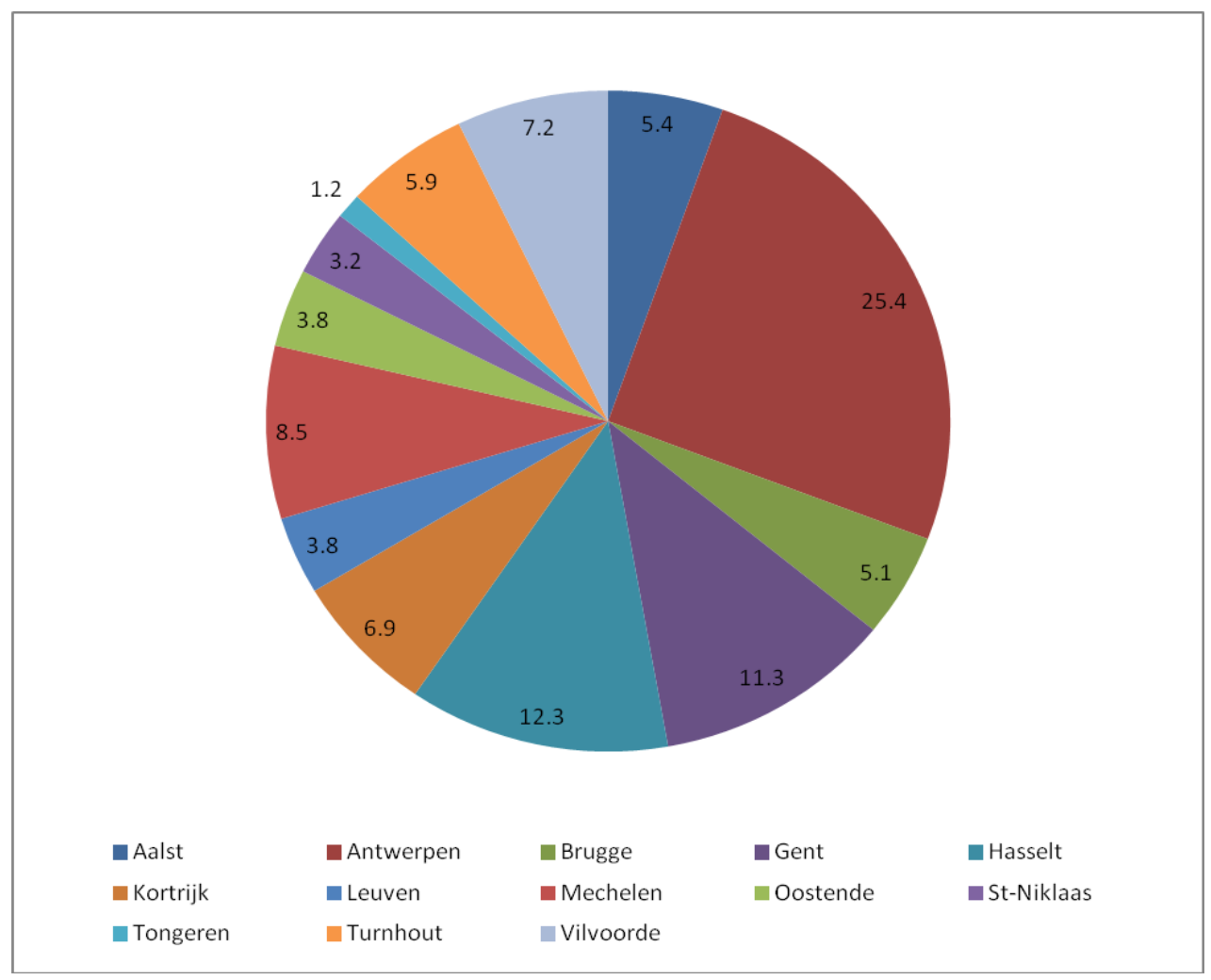

Source: VDAB data on budget 2010, calculations Herman Deleeck Centre for Social Policy - University of Antwerp.

SERR/RESOC receive personnel and operational means from the ERSV by use of a distributive formula. The origin of these means is the Flemish government. An activity report and a financial report, both in a draft and a final version, are required to receive the subsidy. The SERR and RESOC have to provide in these reports all the information required to demonstrate activities and the commitment of the staff members.

The RESOC co-ordinators pointed out that the RESOC budget cannot cover the key issues or initiatives described in the regional planning document. The original idea was that RESOC initiatives, based on their task of advice and coordination, should be covered by Flemish, provincial or local means. As in practice their advice is not adopted by local or central governments, they prefer to take initiatives themselves. The RESOCs scope for policy making is in practice non-existent without any additional, external funding. This search for external funding (such as ESF and EFRO, and VIA ('Flanders In Action'), requires a substantial effort from the staff which causes pressure to be put on the regular activities of SERR and RESOC. Moreover, the sustainability of initiatives that are funded through project funds is argued to be at risk when there is no opportunity to integrate initiatives into mainstream budgets (such as those of the VDAB).

Local governments receive their means from three substantial sources: (1) fiscal receipts from municipal surtax, property surtaxes and other local taxes (typically around $40 \%$ of the budget), (2) general funds provided by the Flemish government (Municipality Fund and City Fund) (typically around 40\%), and (3) earmarked subsidies (typically around 20\%). In addition, municipalities have the opportunity to borrow money as part of their capital budget. The current budget including interest has to be balanced.

Budget flexibility is high for municipalities as far as receipts from funds and fiscal revenue is concerned. All local spending should be covered; costs of personnel, operational costs, transfers for social assistance (PSAC), police, hospitals and other public provisions, and investments and debts. Financial 
means coming from subsidies are earmarked for special services (such as, for example, youth policy) or are defined in a policy agreement. Other means from taxes or the Municipality Fund allow more flexibility. The City Fund falls in between; a programme needed to be put in place in order to obtain resources from the funds. Yet, the programme is not used to determine the amount of money a city receives. Distribution is based on a separate list of criteria. Finally, additional flexibility is created through participation of local governments in public-private partnerships.

\section{Staffing and outsourcing}

Most tenders are outsourced at the regional Flanders level. The PES outsources specific services, mainly training and guidance programmes. Profit, non-profit as well as public organisations can compete for these tenders. However local VDAB offices can, by bottom-up consultation, define requests for local tenders, targeted to specific groups or a specific need. The specification of the tender (the final decision on target groups, area of interest, requirements of the applicants) and the assignment of the tender itself is handled by VDAB at central level in consultation with the local level. Some criticism is heard from the sub-regional VDAB and the local non-profit organisations that the areas of interest are too broadly defined to focus on truly local problems and to involve smaller and specialised local labour market actors (e.g. training bodies, counselling institutions).

Centrally contracted tenders mainly focus on issues such as poverty, outplacement, persons with physical or mental health problems (MMPP) and youth unemployment. Local or regional tenders have a more narrow scope and focus particularly on skills shortages, such as for example care givers, fork lift truck operators, cleaning personnel, etc. These calls can focus on the screening of possible candidates or on vocational trainings for these professions. The initiator of the tenders can be the VDAB at central level, whether or not at the demand of the sub-regional VDAB direction or the provincial competence centres, or the sub-regional VDAB direction itself. In the latter case, the budget of the 'local project programme' (LPP for sub-regional VDAB direction) or 'central project programme' (CPP, decentralised means for the provincial competence centres) is used. As these budget are restricted, this limits the scope of outsourcing actions. The provincial competence centres work together with diverse training partners to complement their own training programmes. Some respondents showed some concern that the introduction of market mechanisms in the provision of counselling may lead to adverse effects on the quality of the counselling.

An example of this tendering procedure is the "Youth Work Plan" tender, which started as an experimental pilot in 13 cities and municipalities, but has been generalised since 2008 for the complete Flanders region. Through this plan, the young unemployed are engaged in a fast and individual approach with direct counselling and an automated matching of job preferences and available vacancies through the PES vacancy databases. This tender is intended for young unemployed people with low chances on the labour market. The unemployed young person is screened on intake and if this screening indicates that general counselling will not suffice, an intensive counselling trajectory with job hunting and job coaching is started. This tender currently counts 4050 trajectories on a yearly basis.

Tendering has been extensively applied for actions that are financed by the Work and Investment Plan 2010-2011 (WIP - Werkgelegenheids- en InvesteringsPlan) of the Flemish Government. The 2010-2011 WIP was specifically targeted to address the fallout of the economic crisis. This plan gives additional means to the PES to generate additional training capacity and to organise training to meet skills shortages and to help job-seekers move towards a new profession or occupation during the economic crisis.

In terms of staffing, VDAB at central level assigns the local VDAB offices and competence centres a certain number of full time equivalents in staff, depending on the local labour market situation. A central team of personnel optimisation, in which the regional VDAB directions are represented, are responsible. Local offices receive a certain degree of freedom to allocate personnel to the different services and 
assignments they have to provide. The majority of the personnel is mobilised for basic services such as labour mediation, training and guidance that are offered at the local level of the 'werkwinkel' and competence centres. The allocation of the personnel must fit into the general personnel framework and the mission of the VDAB. The central VDAB office strictly monitors the personnel framework and labour costs per region and per job category.

Legally, the ERSV is the employer of the SERR and RESOC staff. SERR and RESOC must plan their personnel capacity and requirements and justify them to the Flemish government. Without any structural funding, the available staff can also be charged with executing actions emerging from the regional planning document and, as mentioned previously, the efforts needed to find external funding. The feasibility of outsourcing for SERR and RESOC is not straightforward and depends entirely on external funding and partnerships. SERR and RESOC do not have the capacity to work on specific actions without external support. Actions of RESOC emerging from the regional planning document can only proceed when external partners participating in the projects provide the necessary resources (personnel and/or financial means) or when external subsidies from European Structural Funds or the local, provincial or Flemish government are provided.

Most respondents indicated in the survey that they were able to outsource certain activities.

Chart 6. Flexibility in the field of outsourcing - are local offices able to outsource locally?

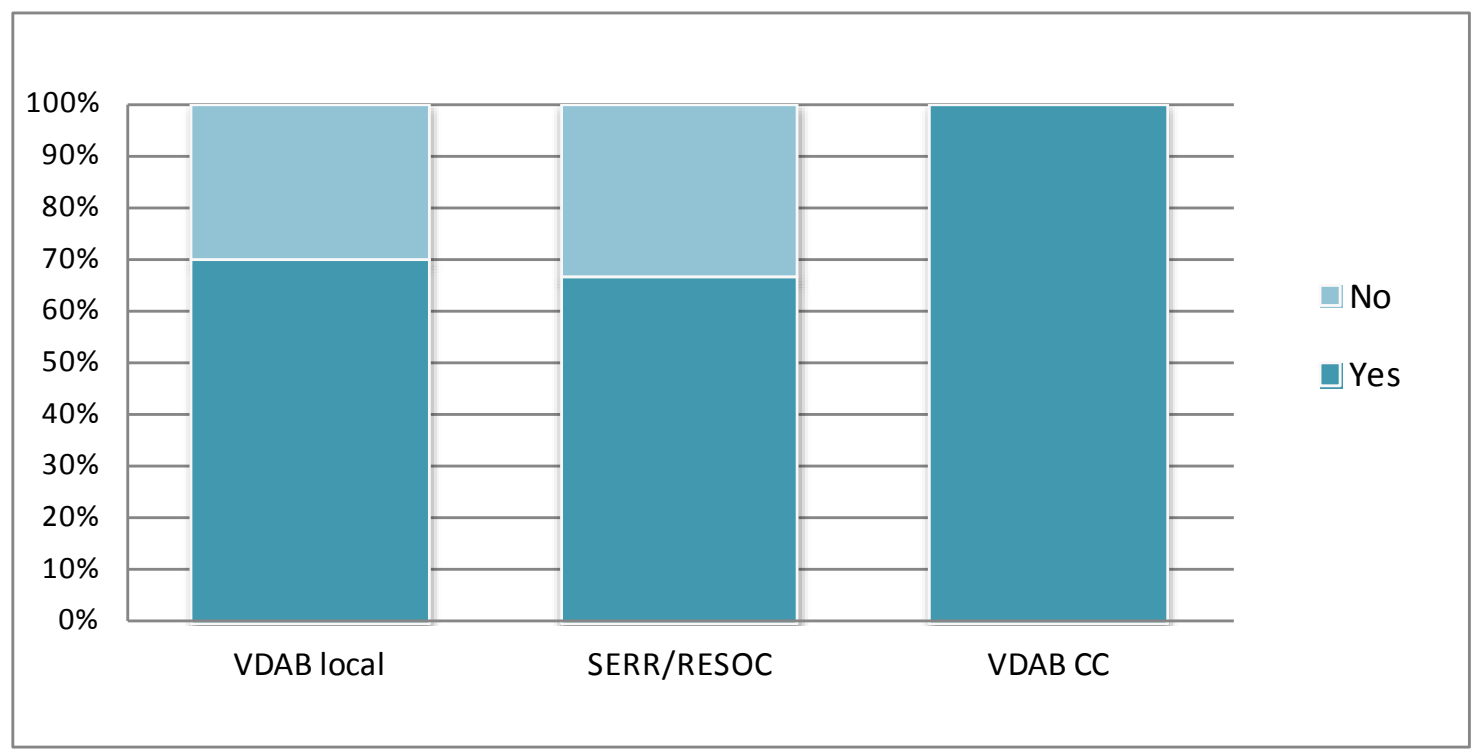

Source: OECD Managing Accountability and Flexibility e-questionnaire.

\section{Collaboration and partnerships}

Flemish local labour market actors work together intensively with each other and with other external partners. As Table 6 shows, the three types of respondents are all involved in one or more mulitstakeholder partnerships, but informal ongoing collaboration is also widespread. Local VDAB offices and VDAB competence centres mainly work with private counselling services, (vocational) training centres and non-commercial providers ("third parties") through outsourcing agreements. The table demonstrates the highly networked nature of the governance structure. 
Table 6. Indication of the number of sub-regional bodies with a partnership, collaboration and/or outsourcing relation.

\begin{tabular}{|c|c|c|c|c|c|c|c|c|c|}
\hline & \multicolumn{3}{|c|}{ Partnership } & \multicolumn{3}{|c|}{ Collaboration } & \multicolumn{3}{|c|}{ Outsourcing } \\
\hline & 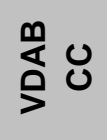 & 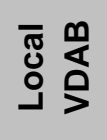 & 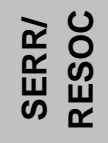 & 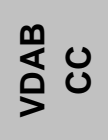 & 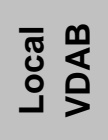 & 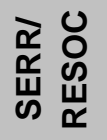 & $\stackrel{m}{\stackrel{m}{0}}$ & 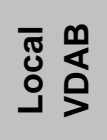 & 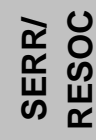 \\
\hline$N=$ & 4 & 10 & 7 & 4 & 10 & 7 & 4 & 10 & 7 \\
\hline Federal/regional government & 3 & 8 & 6 & 1 & 5 & 2 & 1 & 0 & 0 \\
\hline Business & 4 & 10 & 5 & 4 & 6 & 3 & 3 & 5 & 1 \\
\hline Intermediaries & 2 & 10 & 4 & 3 & 4 & 4 & 3 & 8 & 0 \\
\hline Vocational education & 4 & 9 & 5 & 3 & 5 & 3 & 4 & 8 & 1 \\
\hline Tertiary education & 2 & 4 & 4 & 4 & 7 & 3 & 4 & 4 & 1 \\
\hline Secondary education & 3 & 7 & 4 & 3 & 6 & 1 & 3 & 4 & 0 \\
\hline Economic Development & 2 & 5 & 6 & 2 & 5 & 4 & 1 & 0 & 2 \\
\hline Social welfare & 3 & 8 & 6 & 2 & 5 & 4 & 2 & 5 & 1 \\
\hline Non-commercial & 3 & 8 & 6 & 1 & 5 & 4 & 4 & 9 & 2 \\
\hline Sectorial federations & 4 & 9 & 5 & 4 & 4 & 4 & 2 & 7 & 0 \\
\hline Ethnical minorities & 2 & 5 & 3 & 4 & 6 & 4 & 2 & 4 & 0 \\
\hline Local government & 3 & 7 & 6 & 3 & 4 & 5 & 2 & 5 & 1 \\
\hline Other & 0 & 0 & 1 & 0 & 0 & 0 & 0 & 0 & 0 \\
\hline
\end{tabular}

Source : OECD LEED e-questionnaire "flexibility and accountability", January 2011.

Most respondents to the OECD e-questionnaire estimated that collaboration had a substantial impact on the implementation of labour market measures (see Chart 7 below). Collaboration provides opportunities to report on procedures and engagements, but also creates synergies.

Chart 7. The perception on the influence the actors can have on local labour market actions

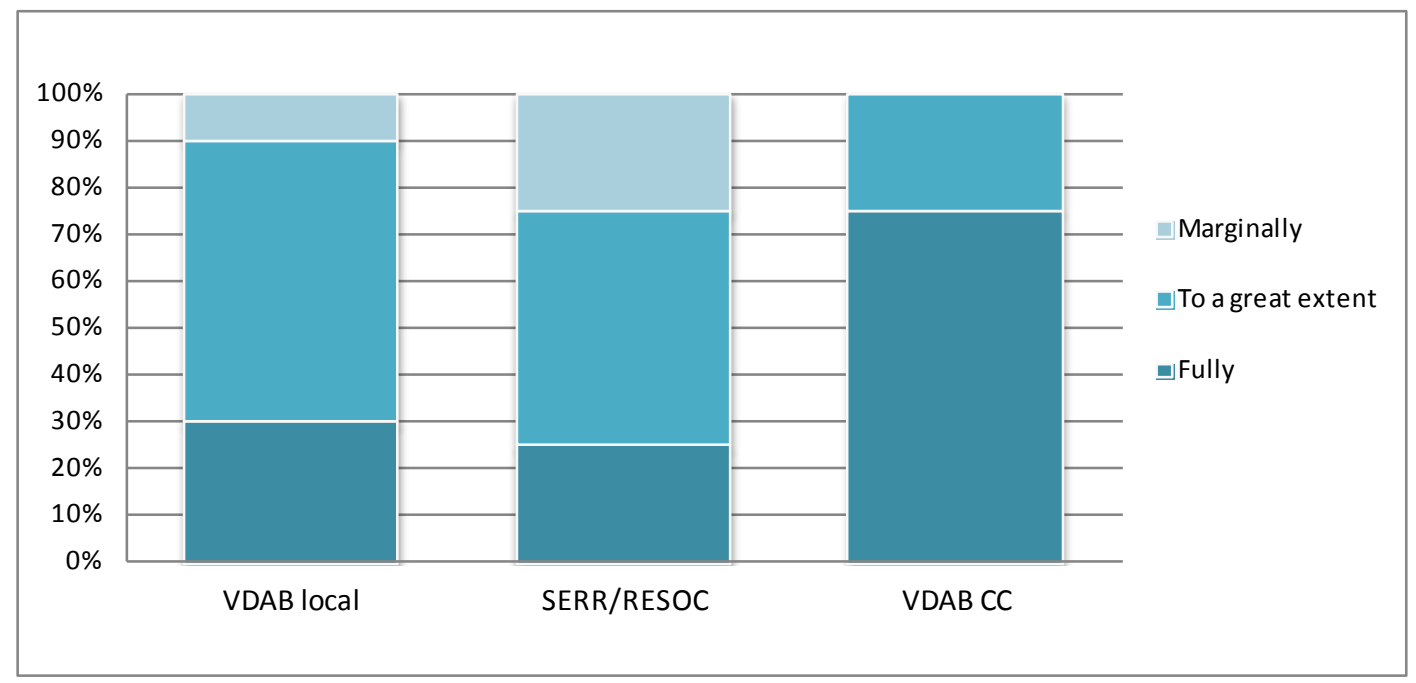

Source: OECD Managing Accountability and Flexibility e-questionnaire.

Examples of the types of projects built on cooperation include: the integration of temporary labour agencies within the 'werkwinkel', helping local governments to expand the local service economy, 
collaboration on training projects, etc. The complementary expertise of the partners is regarded as very valuable. As examples of agreements with partners and sectors, the actors indicate projects such as 'actie direct' with the fruit sector to guide employees with temporary contracts and 'talentenwerf' which consist of a sector initiative to support skills development and skills upgrading in the construction sector. SERR and RESOC give examples of working groups that focus on helping the most disadvantaged into employment, job fairs and a project on competence management in the non-profit sector and in the logistics sector ('Talent Transfer'). The VDAB competence centres see an advantage in mobile training units (in cooperation with local governments) and cooperation with private employers to provide trainings for e.g. crane drivers.

Regardless of the initiating body (city or municipality, RESOC/SERR or local VDAB), local projects and partnerships potentially provide a good opportunity to design local programmes to cover specific and uncovered needs if adequate funding is accessed. The nature and composition of the partnerships which are built to develop such programmes is diverse, as well as the possibilities to subsidise the projects (public and private partners, ESF, EFRO, WIP etc). Two local partnerships are described in Box 3 below. 


\section{Box 3. Examples of local partnerships}

BouwKan Kortrijk: In response to a growing number of unfilled vacancies in the construction industry and the rising unemployment rate, local construction companies, in cooperation with the city of Kortrijk and the local VDAB office, started the BouwKan project. The project focuses mainly on unemployed persons and school-leavers, and intends to inform them about career opportunities in the construction sector and to guide them towards training and a first employment in the sector. The intense involvement of the construction industry itself was mentioned in the roundtable discussions as a point of strength: whereas VDAB counselling is only available to job-seekers while they are still unemployed, the sector itself is able to provide mentors that can continue to guide and counsel the newlyemployed well into their working life, increasing the durability of the employment.

Welding centre in Mechelen: The region around Mechelen has found itself confronted with a severe shortage of trained welders. In response to this, RESOC Mechelen drew up plans to construct a new training centre in the region, named Lascentrum ("welding centre"). The majority of the funds needed were obtained from the European Regional Development Fund (ERDF) (40\%) and the Flemish government (45\%), while RESOC Mechelen and the Campus De Nayer college supplied the remaining budget. Campus De Nayer also supplied the terrain that the centre has been constructed on. The centre will be managed by an assembly of various local and sub-regional organisations involved in training or with vacancies for newly-trained welders. The coordinator of RESOC Mechelen revealed that gathering the necessary funds took an estimated six times longer than the actual building of the centre.

Efforts to bring together all the different actors engaged in labour market policy in Flanders are supported through a partnership agreement developed in 2005 (see Box 4 below). A key mechanism for bringing together the different actors are the local one-stop job shops (werkwinkels). These represent a local partnership of PES, Public Social Assistance Centre, Labour Counselling, LEA, NEO and other local actors. The one-stop shops focus on providing integrated services on work and employment and on information on the local service economy. Common in these agreements is that VDAB takes the role of coordinator of integrated basic services and the local government takes the role of coordinator in relation to the local service economy. In practice, however, not all one-stop job shops offer a truly integrated and comprehensive service (Struyven and Van Hemel, 2007). 


\section{Box 4. Bringing together the regional, sub-regional and local levels for the implementation of employment policy}

A partnership agreement was signed in 2005 to develop a more coordinated approach to local labour market policy. Starting from April 2005, the "Partnership agreement on local employment policy" aimed to reinforce local employment policy by structuring its institutional architecture on three different tiers: the federal government, the Flemish government and the local authorities (represented by the VVSG, the municipal association of all Flemish cities and municipalities). The architecture intends to allow for flexibility, so that labour market policy can be implemented in different ways at local level. One of the main commitments of the different governmental levels was to inform all other partners on future policy decisions with consequences for local employment policy before implementation and to maximise policy integration and co-ordination. The three partners were asked to develop a transparent, customer friendly and free network of services built on the local one-stop job shops.

The responsibilities of each actor are as follows:

- The commitments of the federal government, in particular, mainly concern the services of the LEAs, the promotion of federal employment and activation measures and the promotion of the local service economy (such as the service cheques, fiscal advantages for certain services).

- The regional level focuses its contribution on providing integrated employment services for employers, employees and jobseekers that are customer friendly, transparent and free. They also have to provide relevant labour market information and statistics and to integrate and co-ordinate their services and instruments of counselling with those of the other partners, to stimulate and co-ordinate cooperation of different partners and actors, to develop new services for the local one-stop job shops and certify the actors involved.

- The VVSG, which represents the local authorities, commits itself to participating in workgroups on the local employment policy theme and to providing relevant policy input into consultation forums. VVSG must also support local authorities in developing employment policy and extending the local service economy.

- The local authorities themselves take the lead in developing the local service economy. Their task is to disclose the local offer of services and employment, to develop a local service economy within the intergovernmental agreements with attention to local policy choices, to co-ordinate the further development of the service economy with attention to unanswered needs and employment creation (also for disadvantaged groups), to recognise local initiatives (with exclusive local financing) or advise on recognition (with several financing bodies) of new service economy initiatives and to communicate recognition and financing of local initiatives to the Minister of Social Economy.

The partnership agreement defines three instruments to support local employment policy: the one-stop shop or 'Werkwinkel', the Local Employment Policy Forum and a Task Force.

- The werkwinkel is a local partnership of VDAB, OCMW, Labour Counselling, LEA, NEO and other local actors to build integrated services on work and employment and on information on the local service economy. The werkwinkels are responsible for a 'care-area', which can be a part of a city, a municipality or a cluster of municipalities.

- The Local Employment Policy Forum consists of (at a minimum) representatives of the city or municipality (functioning as chairman), the Public Social Assistance Centre, the PES, local third parties, social partners of employers and employees, the NEO, the labour counselling (ATB) and the executive board of LEA. The Forum acts as a body for advice and consultation.

- The Task Force must guarantee the exchange of information between the contracting partners, the evaluation of engagements and the formulation of proposals for improvement. 
Local Employment Policy Forums have also emerged which consist of representatives of the city or municipality (functioning as chairman), the Public Social Assistance Centre, the PES, local third parties, social partners of employers and employees, the NEO, the labour counselling (ATB) and the executive board of LEA (see Box 4). Most of these partners are also part of the one-stop job shops 'werkwinkel'. The Forum acts as a body for advice and consultation. Its tasks are to approve a strategic action plan for local employment and a joint report for central, regional and local governments; to optimise the cooperation of all local actors; to stimulate joint actions; to maximise the use of federal and regional instruments for disadvantaged groups and jobseekers in broad sense; to advise on the activities of the local one-stop job shop and on actions to support the local service economy and to inform the RESOC at least once per year on the work of the local one-stop job shop. The Forum is established by a local agreement. The agreement stipulates that local governments take the role of political director of local employment policy (which means they are responsible for institutional mapping at the local level, the definition of common policy lines and the organisation of collaboration) and the role of director in relation to the local service economy. In practice, however, it is not clear whether or not the Local Employment Policy Forums perform their tasks and whether or not they contribute to better functioning local employment policy.

The VDAB also carries out what is known as local partner consultation (Lokaal Partneroverleg). Local partner consultation is organised twice a year in each province and on the initiative of the VDAB. Operational local partners of the VDAB (involved with the services that they offer) are informed about training initiatives, guidelines, cooperation and the VDAB policy (such as its strategic objectives). At the same time, they can make comments back to the VDAB and highlight possible areas of skills shortage. This consultation is not intended to be the basis of a decision making, but only to provide two-way information for the different partner organisations. These partners are, for example: training centres, local third parties, labour counselling for disabled persons.

Partnership working was not always assessed to be successful in producing integrated approaches to labour market challenges however. Respondents to the e-questionnaires highlighted continued difficulties in tackling barriers to the labour market (such as lack of child care, lack of mobility), creating chances for disadvantaged groups and meeting skills shortages. This observation was echoed in interviews with local actors, who mentioned that the reason for the limited capacity of local governments in tackling such barriers to the labour market is due to 'policy silos' and the compartmentalisation of the Flemish government. For example child care and education are delivered by separate departments which develop policies with different logics of intervention. Local actors also cited the lack of financial means to develop cooperation and actions, and also indicate problems with sectors, employers and jobseekers who hesitate or refuse to cooperate.

\section{Strategic collaboration}

Partnerships and collaborations are situated not only at the operational level, they also play an important role in different bodies involved with advice or consultation. Flanders has a widespread range of counsels, agreements, forums and collaborations that operate according to a top-bottom blueprint. In this case organisations cooperate because an agreement ensures that they cooperate.

The SERR and RESOC are also seen by many to have an added value in co-ordinating the different objectives of partners and partnerships, although local stakeholders expressed a lack of faith in their ability to effectively design effective local labour market policies, particular as the advice of the SERRs and RESOCs is not anchored in Flemish policy. Due to the governance level at which they operate (which does not coincide with city governments for Antwerp and Ghent) there is not always an easy fit between these strategic platforms and the city planning process. In Antwerp for example the municipality places most emphasis on developing city-wide strategies which bring in a diverse range of partners and resources. In addition, the difference in the labour market context between the city and the residential belt around the 
city (also included in the RESOC) is significant, which can make operational cooperation more difficult at the RESOC level.

In addition, partnership working does not always influence the development of strategic plans and priorities for the different labour market actors. The central priorities of the action plan of the city of Antwerp are for example not found in the yearly action plan of the sub-regional VDAB office. The subregional VDAB direction has to meet the VDAB targets and has adapted them most recently to meet local conditions such as language policy, the need for more on the job training and the need to extend cooperation with SMEs. However the city has other priorities. While youth unemployment is a priority for both the city and the VDAB, tackling entrenched labour market barriers (e.g. childcare and mobility), the optimisation of local service economy and the alignment of education and labour market policies are not part of the annual VDAB targets.

\section{Institutional crowdedness}

The term 'institutional crowdedness' can be used to describe the density of different organisations and collaboration mechanisms that exist in Flanders. The region of South West Flanders, one of the roundtable cases for this study, gives a good indication of the issue. An institutional mapping across policy sectors has resulted in an inventory of no less than 134 formal and informal collaboration arrangements on public policy issues (De Rynck, 2010). The networks are public/public, public/private or (semi-) private/(semi)private. The growth follows an exponential curve: 70 organizations out of those 134 were initiated after the year 2000. The networks relevant for work and social economy are listed below. Comparable exercises in other regions seem to paint a roughly similar picture.

In the field of employment and social employment:

- Commission EAD (equal participation in the labour market and diversity) (SERR)

- Forum labour market (Kortrijk, Harelbeke, Menen, Waregem, Wevelegem, Zwevegem)

- Halte R

- Kanaal 127

- Landschapswacht within vzw Constructief (landscaping and maintenance services)

- Consultation Local Services Economy (RESOC en Sinergiek)

- Project Energiesnoeiers ZW-Vl (project to reduce energy consumption)

- $\quad$ SERR Zuid-West-Vlaanderen

- SINERGIEK

- $\quad$ vzw Kringloopcentrum (recycling centres)

- Working Group Trajectbegeleiders (traject counselers) (SERR)

- Werkwinkels: Kortrijk, Harelbeke, Menen, Waregem, Wevelegem, Zwevegem

In the field of entrepreneurship:

- Design Regio Kortrijk vzw

- Eurometropool: Thematic Working Group Economy

- Financial Forum

- Innovation centre West-Vlaanderen

- Intermunicipal working Group Local Economy (Leiedal)

- Kortrijk.IN

- My Machine vzw

- $\quad$ Business Centre (Ondernemerscentrum)

- Regional Platform for starters (startersbegeleiding) (RESOC)

- Working Group sustainable communiting (woon-werkverkeer) (RESOC)

- Working Group R\&D (O\&O, productontwikkeling, design, kunststoffen, ...) (RESOC) 
In the field of training and education:

- $\quad$ Regional Platform Part-time learning and working (Deeltijds leren en werken) (RESOC)

- School communities (Schoolgemeenschappen)

- $\quad$ Steering Group education

- Working Group part time learning in care sector (RESOC)

- Working Group onderwijs en opleiding (RESOC)

- Working Group Technisch onderwijs (RESOC)

- Working Group Tertiair Onderwijs (RESOC)

The absolute numbers should be put into perspective. Different kinds of arrangements have different degrees of formalization. Yet, the list provides an indication of the complexity of the issue. Some networks host different sub-networks. RESOC/SERR for instance has 17 networks under its wing. $71 \%$ of the networks do not have a legal person and remain unincorporated; these are mostly lighter forms of coordination. Some of the networks are initiated based on Flemish or federal legislation; RESOC/SERR, LOGO's (Local Health Care Consultation) and Zorgregio's (care regions) are examples. Most are initiated by local actors. $88 \%$ of the networks have an area of operation within the region Zuid-West-Vlaanderen. The apparent complexity may also indicate dynamism of actors to cooperate on social issues.

Two causes for institutional crowdedness can be identified. Firstly, Flanders is not an exception to the international trend of developing policy silo's (Froy \& Giguère, 2010). In Flanders, this trend is known as compartmentalization (verkokering) of Flemish policies. During the last two decades, the Flemish government increasingly involved local governments in policy making through subsidies. The requirements for getting these subsidies however were almost exclusively based on sectoral logics. As a result, central (Flemish) compartmentalization was exported to the municipalities. In the next phase, and mainly because of tendencies to increase scale in several sectors (health, youth care, education, etc.), regional governance also developed in compartments. Thus, compartmentalisation developed in three steps; first at the central level, next at the local level, and then at the regional level. At the end of the day, the silo runs from the lowest to the highest tier of government. At the same time, match funding requirements, where subsidies are provided under the condition that other tiers of governments also supply funds can also confuse accountability relations. It should be added that in comparison with other countries, Flanders has relatively frail co-ordination mechanisms at central level. The power of horizontal departments such as planning, budgeting and finance is relatively weak (Bouckaert \& Halligan, 2008). The New Public Management (NPM) flavoured reform 'Beter Bestuurlijk Beleid' of the early 2000s led to specialisation and the proliferation of agencies, which further hindered the capacity to co-ordinate.

A second reason for the birth of many new institutions is the mismatch between social and economic reality and the working areas of the governance structures. Two manifestations of this mismatch can be identified. In rural areas, municipalities are too small to build sufficient capacity to tackle many problems (see Chart 8 below). Therefore, they develop local partnerships to improve their capacity to act. In many cases, these bottom-up networks make very good sense. In urban regions, the administrative borders no longer coincide with urban areas. Antwerp, for instance, has approximately 480,000 inhabitants while the number of inhabitants in the urban area is roughly 630,000. The number of inhabitants in the broader Antwerp region is estimated at nearly 1 million. Again, partnerships and networks may remedy this mismatch and enable policy making across administrative borders. 


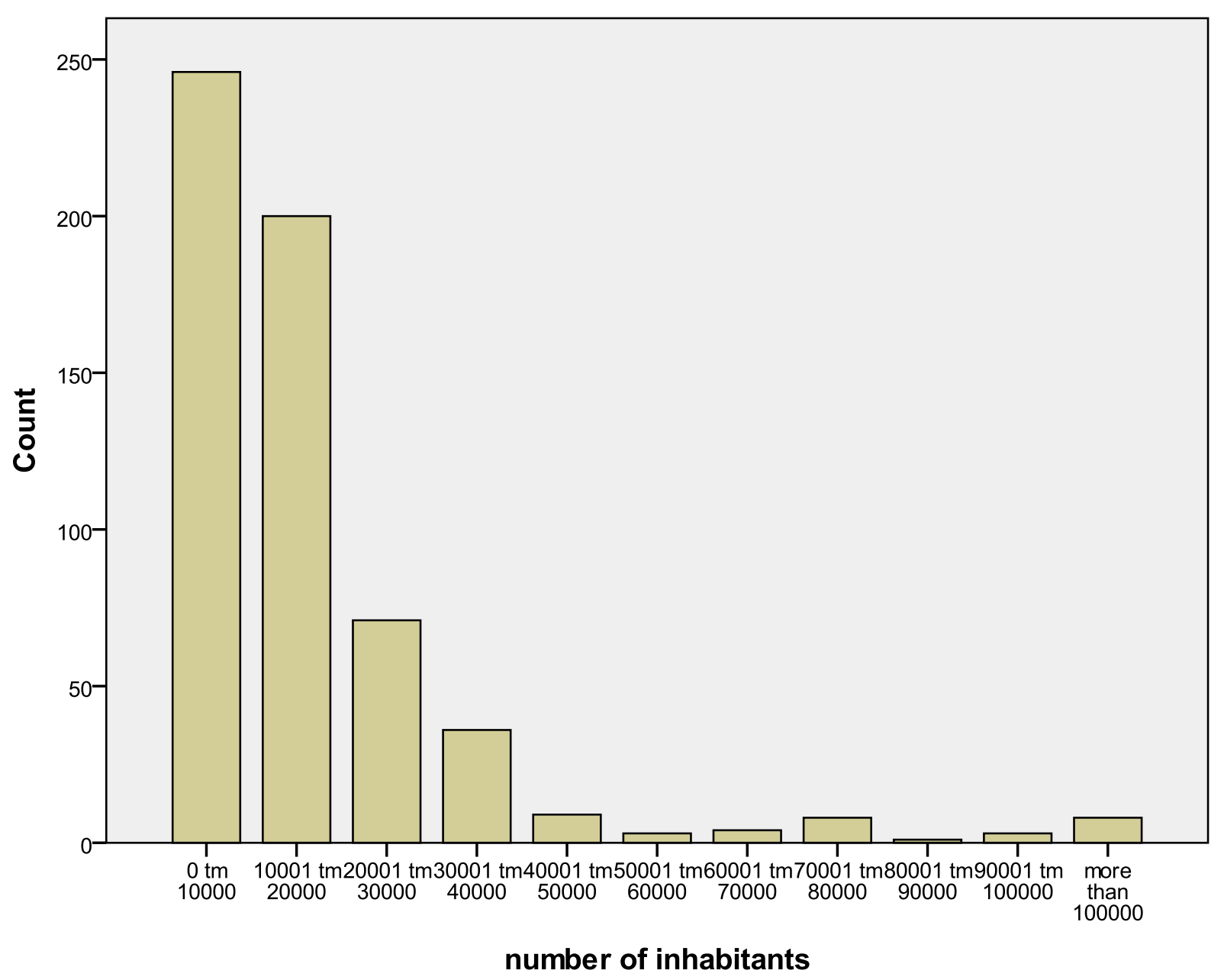

Source: FOD Econom-e - Algemene Directie Statistiek en Economische Informatie (AD SEI)

Although many networks and collaborations are initiated with good intentions and based on an objective need, the sheer number of them may have some negative consequences. Firstly, effectiveness of these structures could probably be higher if there would be more co-ordination. Secondly, it becomes increasingly difficult for elected politicians to monitor what is going on in these networks. When intermediary structures develop local policies and/or work with local funds, in particular, a democratic deficit may arise. Thirdly, institutional crowdedness may form an issue for citizens and businesses. Within the same region, 10 organisations of different governments have responsibilities for innovation (De Rynck, 2011). As a result, there is no clear entry point for support.

In response to these issues, the Flemish government (2009-2014) has initiated an ambitious agenda for reform of intergovernmental relations between tiers of government (see the 'Future Directions' section below).

\section{Overall perceptions of flexibility}

Charts 9 and 10 below show the overall flexibility that local actors perceived they had in the management of labour market policy. In general, the overall level of flexibility available to labour market actors (VDAB and the RESOC/SERR) was perceived to be moderate to high by respondents to the OECD 
e-questionnaire. However, these actors felt that their influence on budget management was somewhat lower.

\section{Chart 9. Perceived overall flexibility to deal with local problems}

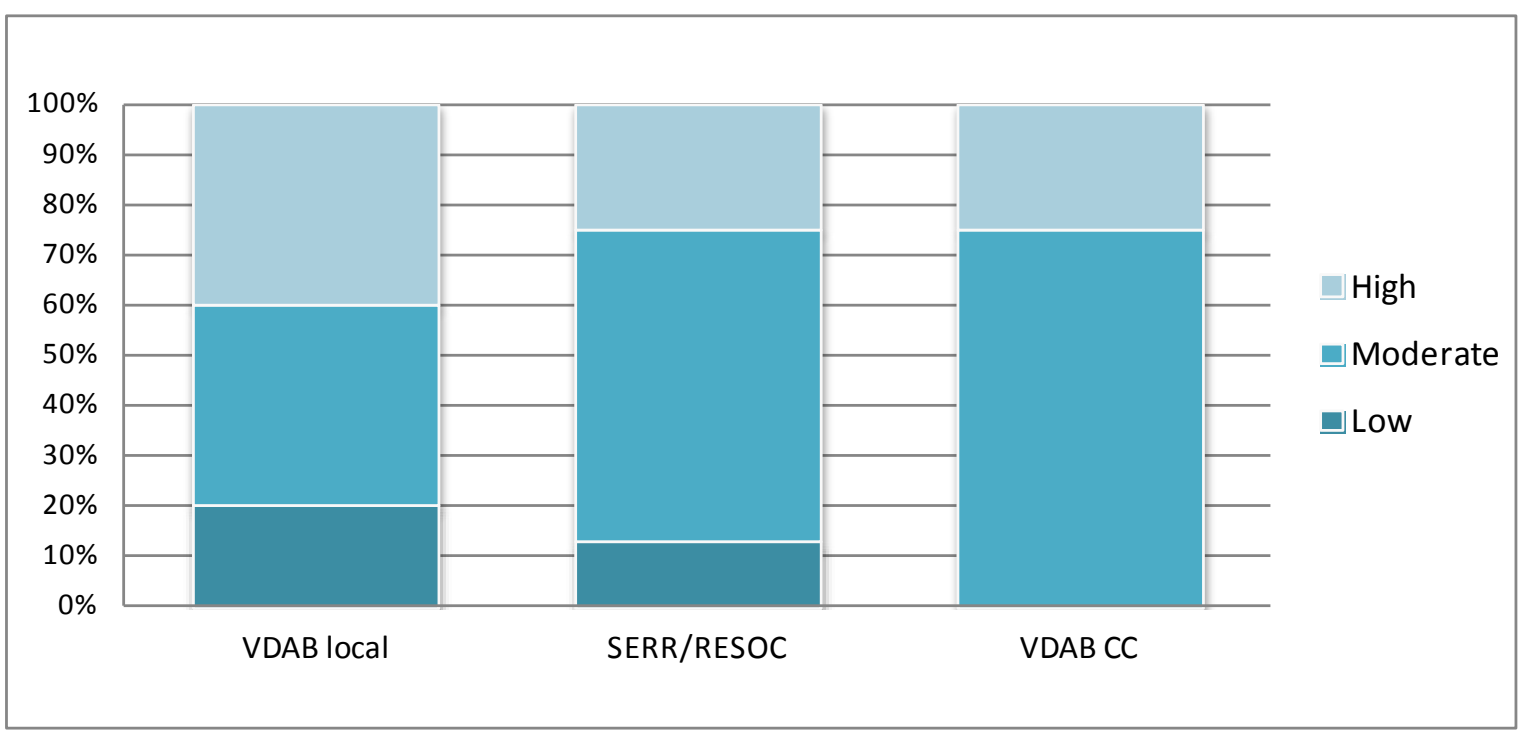

Source: OECD Managing Accountability and Flexibility e-questionnaire.

Chart 10. A summary of perceptions of flexibility in the different management areas

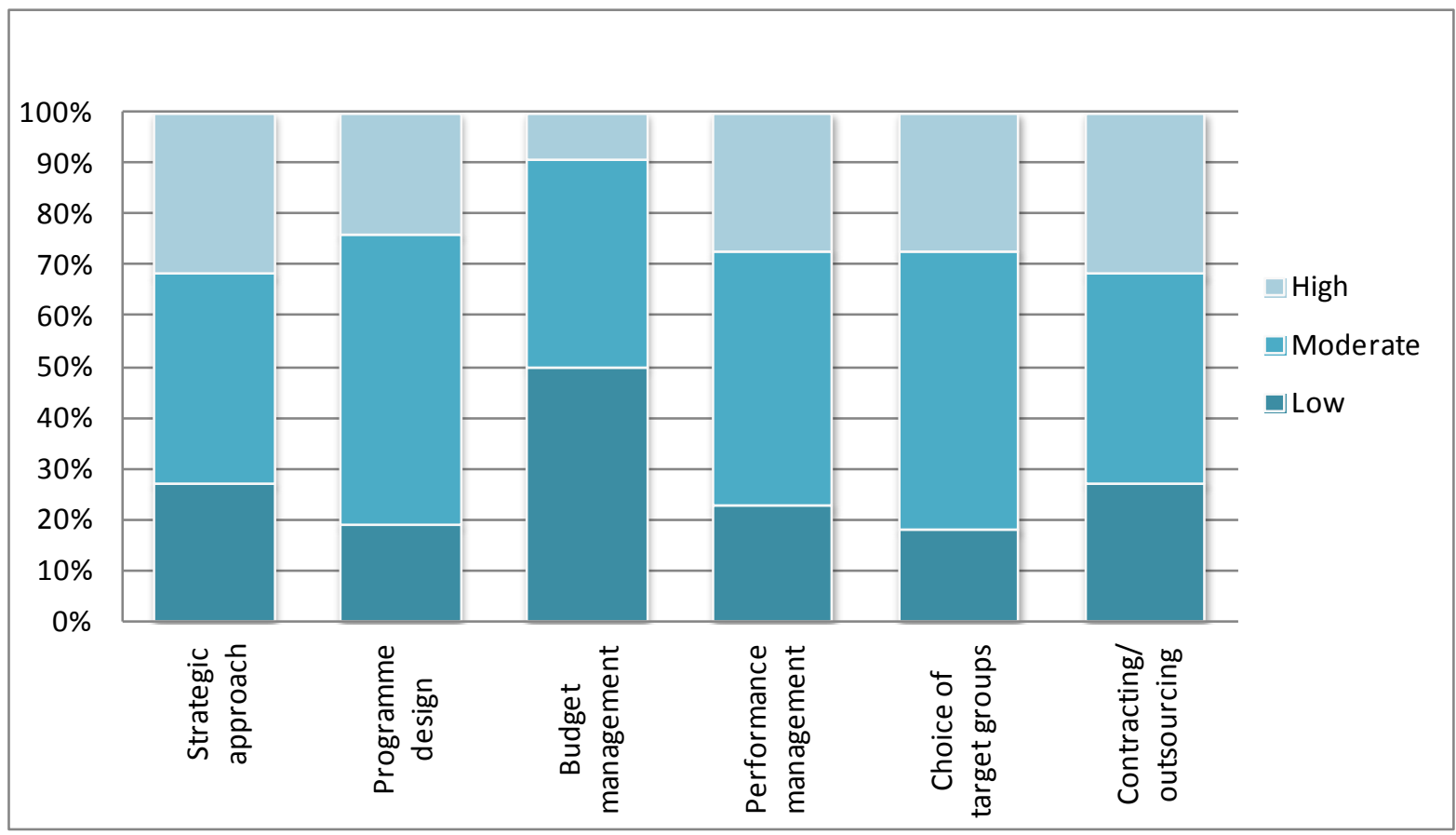

Source: OECD Managing Accountability and Flexibility e-questionnaire.

When the responses of the 13 VDAB sub-regional labour market management offices are separated out from those of other stakeholders, the perceptions of flexibility in the different management areas are as follows: 


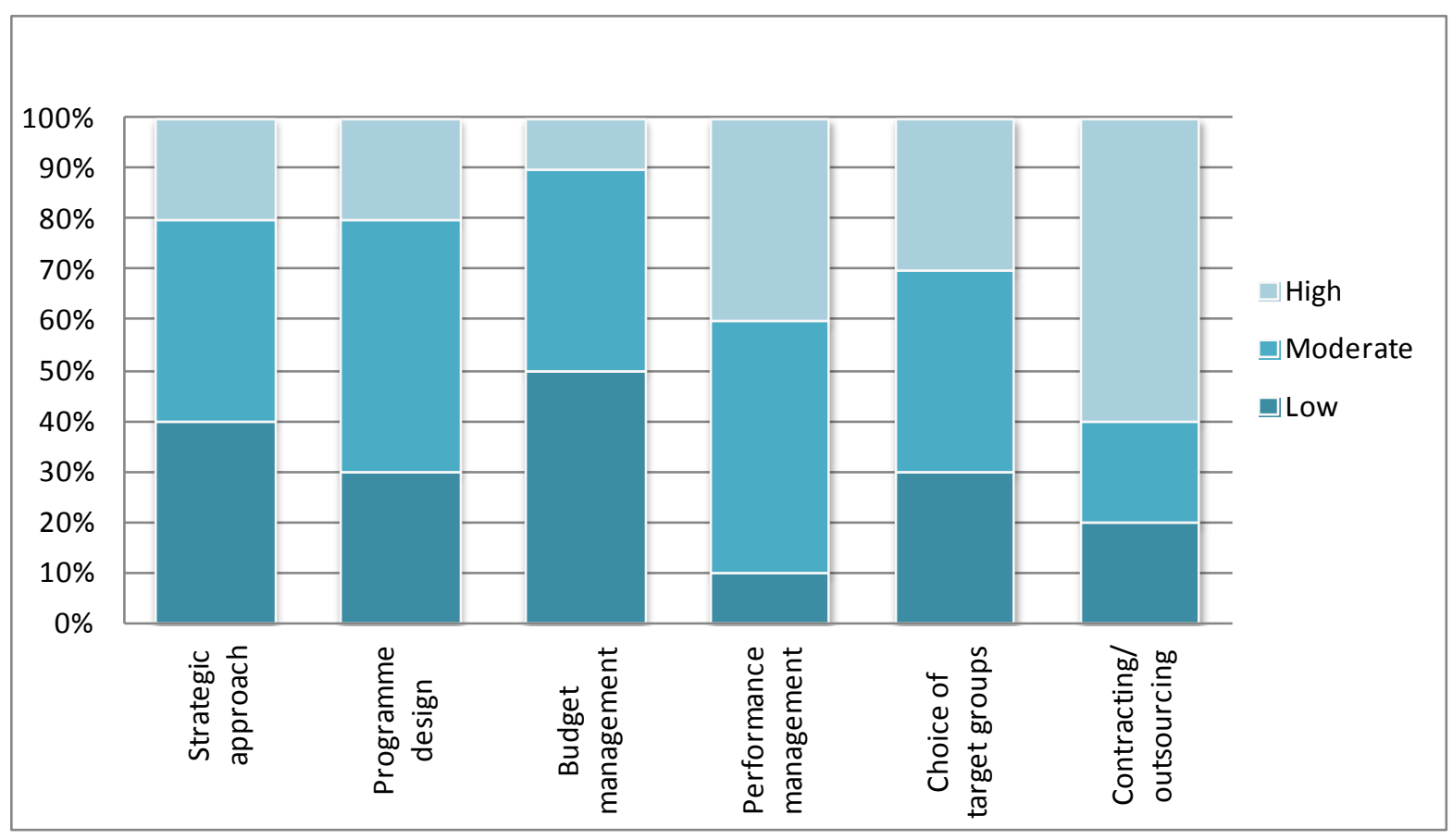

Source: OECD Managing Accountability and Flexibility e-questionnaire.

The roundtables and the interviews provided additional elements to this overall picture. The PES offices reconfirmed that the flexibility they received from the central PES division was adequate and improving - although some minor adjustments might be useful. They also pointed to the internal reform of the PES (known as 'provincialisation') as an opportunity to further improve flexibility in meeting the needs of local labour markets. The RESOC/SERR confirmed that they had freedom in addressing local labour market issues. The main limitation they reported is the lack of their own core funding to implement policies as encoded by the sub-regional planning document (streekpact).

Both in interviews and in the roundtable discussions, a more critical position was taken by local governments - more so by the city of Antwerp and the municipal association VVSG than by the city of Kortrijk. Local governments argue that the PES is not sufficiently responsive to the local needs and policy preferences. Although the formulation and implementation of JOP (yearly business plan) is fed by local actors and policy advice, it is argued that the few concessions the PES is making towards local preferences and policies are ad hoc and based on goodwill. The PES leadership confirms that it will only consider further engaging with local government when adequate policy capacity is proven. For the time being, the PES leadership only sees this capacity within the large cities, i.e. Antwerp and Ghent. For now, with both cities (and the OCMW), the PES has a special agreement to elaborate an 'inclusive and coherent city policy on activation, labour market and employment'. The partners acknowledge the different directing roles and tasks (which already exist within the legal framework or by agreement) and agree on cooperation (with or without other organisations and sectors) on issues as for example labour market preconditions, alignment of education and labour market and specific projects. In practice however, the partnership agreement merely defines the responsibilities of the different partners. It does not initiate a joint policy plan. After the introduction of the provincial level within the VDAB, VDAB plan to implement the collaboration with Antwerp and Ghent by means of city managers. These city managers would introduce a more strategic cooperation between the city and the PES. 
The ability to make strategic and programme design choices and to define target groups were seen as a high priority for further flexibility. A necessary condition was, however, more capacity and/or resources locally. It was felt that more flexibility would facilitate a faster response in reaction to labour market change, a more realistic target group choice (especially to address actions towards specific disadvantaged groups), targeted actions to sub-regional or local needs (e.g. coastal areas) and also the elaboration of a more personal and tailor made approach for individuals. On the organisational level, a more flexible choice of partners for cooperation (e.g. to more easily involve small locally based organisations) and a more personal interpretation of the (division of) tasks of coordinator and actor (e.g. as defined in the partnership agreement on local employment policy or the agreements between cities and VDAB) were felt to be possible ways of introducing more flexibility. 


\section{FUTURE DEVELOPMENTS}

\section{Changes to the management structure of the VDAB}

This is a time of important change in the governance of labour market and other related policies in Flanders. In the section below we briefly summarise proposed changes to the management structure of the $\mathrm{VDAB}$, which are being accompanied by a wider process of state reform.

The management structure of the VDAB is currently undergoing review. In particular, it is planned to introduce a new intermediary 'provincial level' of governance between the 13 sub-regional PES offices and the VDAB central office (the competence centres are already organised on the provincial level). All 13 offices would belong to one of the five provincial managements. The co-ordination of the provincial management of the competence centres and the sub regional labour market offices would be organised by a provincial management board. This board will take, for example, the final decisions on the spending of the local project programme budget. For the daily management of the sub-regions, a regional manager is appointed within the provincial management. The 13 sub regional teams would still be driven by a team leader but the 13 offices will only remain as front offices, entirely under the leadership of the provincial director. The VDAB's rationale for this reform is mainly efficiency gains. By bringing responsibilities to a higher level, economies of scale are sought. It is also thought that the new provincial level will make the management of the VDAB more 'bottom up', since all regional provincial directors will be represented in the main managerial decision making centre - the direction committee - giving them a stronger voice. It is expected that the directors of the provincial offices will organise their subdivision in such a way that the division takes intra-provincial differences in labour markets into account (i.e. by appointing regional or city managers). This reorganisation is on-going and will be finished in 2012.

\section{The Flemish reform of the state, and a new role for municipalities}

The current reform of the state government (see Box 5 below) also proposes a thorough review of administrative oversight of municipalities. The proposal is to move from specific to general oversight. General oversight is laid down in the municipal decree, and looks at the general functioning of local governments, finances, personnel matters, etc. Specific oversight is added to general oversight, mainly by sectoral decrees. Usually, this type of control is conceived from a sectoral logic and sectoral policy objectives. Local governments complain about a lack of co-ordination of specific oversight, another instance of compartmentalisation. 


\section{Box 5. Intergovernmental relations in transformation: the Flemish reform of the state}

The Flemish government (2009-2014) initiated an ambitious agenda for reform of intergovernmental relations between tiers of government. In its coalition agreement, the political parties of the majority (Christian-Democrats, Socialists, and Flemish-Nationalists) formulated the ambition to reduce the institutional crowdedness ("bestuurlijke drukte") in Flemish policy making and implementation. This agenda refers to the number of public organisations and tiers of government that are intervening on a specific policy matter, which is assessed to be inefficient and to create administrative burdens. Moreover, this issue is formulated as a cross-cutting one. In virtually all policy sectors, competences are distributed across tiers of government. Hence, all policy sectors were affected. The problem was generally believed to be mainly situated at the so-called intermediary level between local (municipal) and central (Flemish) level. The coalition agreement mentions the provinces, the intermunicipal cooperation, as well as deconcentrated and other intermediary governance arrangements.

The reform agenda is still under development. Each policy sector had to set up a process of analysis, including proposals for action that were published in a green paper. This green paper was approved by the Flemish government in July 2010, and sets the scene for an ongoing round of discussions that should lead to the approval of a white paper containing the decisions that will be taken. This white paper is expected in Spring 2011. Afterwards, its implementation can be initiated.

The principles and the policy agenda of the Flemish reform of state are strongly interconnected with issues of local autonomy and flexibility on the one hand, and accountability on the other. It is about responsibilities for policies, but also about efficiency and effectiveness of service delivery, about facilitating cross-sectoral cooperation, and about democratic accountability. For the policy sector Work and Social Economy, the LEED OECD review is expected to be an input in this process. This chapter summarizes the main components of this horizontal governance agenda.

\section{Subsidiarity and the two-tier logic}

There are two main principles behind the reform agenda - the first principle is subsidiarity and the two tier logic.

The principle of subsidiarity is firmly anchored in legislation. Local government in Flanders has a constitutional right to develop all policies that are of local interest. The municipal decree of 2005 further stipulates that municipalities define for themselves what is of local interest. They can take up any local task, unless this is forbidden by higher legislation. This is relevant in the context of local labour market policies, since there is no legal restriction on local governments for developing activities in most of the areas of local labour market policies.

The coalition agreement as well as the green paper subscribe to the principle of subsidiarity which implies that tasks should be performed at the lowest level possible, unless there are good reasons to put a task at a higher level. In the policy documents, those reasons for not using local actors are not explicitly stated. From the literature, we could think of services with a redistributive character that service a broader region (e.g. major cultural institutions), that might initiate dysfunctional competition (e.g. social housing projects, zoning), that involve major planning and co-ordination tasks (e.g. large road infrastructure), or that generate major economies of scale (e.g. fiscal administration). Since there is no agreed upon list of criteria, subsidiarity is not widely used as a guideline in actual discussions.

Something that does play a role in the discussions, however, is the principle of two-tier intervention. The general idea is that on each policy issue, only two tiers of government may interfere. This rule should be read together with the statement that in Flanders only two tiers should have open competences; the municipal and the Flemish level. This implies that only the local and the Flemish level should be able to develop policies on their own initiative. They should do this within the realm their mission statement which is, according to the constitution, all that is of municipal or 
regional interest, respectively. For now, the constitution also provides these open competences for the provinces; but the Flemish coalition agreement wants to change this to "a closed list of area-based competences". There is no clear motivation why the Flemish coalition agreement opted for area-based competences for the provinces, but it seems likely that in this way, policy makers could keep the reform out of the complex institutional setup of Brussels.

The formulation "area-based competences" for the provinces refers to a key feature of the Belgian institutional design; the distinction between area-based and person-based competences. Area-based competences are the responsibility of the regions (Flanders, Wallonia, Brussels) while person-based competences are the responsibility of the communities (French-speaking, Dutch speaking and German speaking). In Brussels, both communities and regions are operating. A Dutch speaking inhabitant of Brussels will receive education from the Flemish government, but receive zoning permits from the Brussels region. For the field of labour market policies, labour mediation services are seen as economic and thus an area-based, regional competence, while professional training is a person-based service, and thus a responsibility of the communities. In Flanders, both competences are brought together under the auspices of VDAB. In Brussels, VDAB only provides training services while the job placement and mediation is the responsibility of ACTIRIS.

The media and politics see the reform of the provincial level as the focal point in the Flemish reform of state. It also seems to be the field in which least progress is being made. The two other projects of the reform package, however, receive less attention, but are probably of higher importance, in particular for the purposes of reviewing local labour market policies. They also reconfirm the two-tier logic and the principle of subsidiarity.

Administrative oversight is planned to gradually shift from ex-ante to ex-post, leaving more room for local governments. This shift echoes a new approach to accountability based on responsibility combined with accountability for attained results. There are also plans to simplify administrative burdens by installing a single audit. It should be noted however that this is a long haul trajectory. The shift from a legalistic ex-ante to a results-based ex-post control is more of a matter of culture than of legislation and organisation.

A second project that aims to strengthen the local level as the base for policy and administration intends to combat what is widely known as local planning burdens (planlast). The planning burdens are an example 'par excellence' of the impact of policy silos on local governments. In the last two decades, increasingly more policy sectors provided earmarked subsidies to local governments under the condition that a local policy plan was written. In this way, Flemish policy makers wanted to combine local flexibility in policy making with accountability to Flemish policy objectives. However noble and well-conceived these initiatives were, they produced some unintended side effects. Because of the high number of such planning obligations - some years ago, the municipal association counted 34 planning requirements coming from higher tiers of government - local governments could not mobilize sufficient capacity to set up genuine planning procedures. Moreover, the timing and duration of the planning cycles did not respect the local electoral cycle, which made it difficult to secure commitment from local politicians. At the end of the day, planning was perceived at the local level as an administrative burden; a bureaucratic exercise 'for Brussels', needed to secure subsidies.

Currently, an innovative decree on planning burdens is in the making. Now funding provided against a sectoral decree will no longer be allowed to demand specific planning documents from local government. Yet, this does not mean that local governments no longer have to do any planning. One local plan remains mandatory; i.e. the strategic multi-year plan that is required by the municipal decree of 2005. This plan is aligned to the municipal political electoral cycle, and fits in a broader policy and management cycle. It has to be submitted in the year following the elections and is annually reviewed. Moreover, it is tied to the yearly budget preparation and control procedures. Policy sectors are still able to provide earmarked 
subsidies. Yet, accountability for the subsidies spent should be evidenced through the strategic policy and management cycle. The aim hence is to make local planning meaningful for local policy makers, without barring the opportunity of higher governments to provide stimuli and to ask for accountability. The planning process in this way should be more important than the planning format.

Both administrative oversight and the reduction of planning burdens set the stage for rethinking accountability between local and central governments. The lessons learned so far from these efforts may be relevant for labour market policies as well.

- First, it appears that that there is an undercurrent in policy making to provide more responsibilities for the local level.

- There is also a widely shared belief, at least rhetorically, that more ex-post outcome-based accountability is favourable.

Yet, a legalistic administrative culture causes these processes to backslide once in a while.

In general, the new policy and management cycle in local government will in all probability be a big step forward in the professionalization of local governance. It may prove to be a window of opportunity to apply the principle of subsidiarity in practice.

\section{Local governance capacity}

Another focus of the Flemish State reform is to increase the capacity and size of local municipalities. One critical success factor, mentioned by many observers, is the capacity of local governments to take responsibilities for policies into their own hands. Indicators for local governance capacity however are not defined and often the discussion on capacity refers to the scale of local governments. Flemish local governments are relatively small compared to Nordic countries, but large in comparison with France or Italy. Moreover, there is high diversity amongst municipalities. Two thirds have fewer than 20,000 inhabitants. Thirteen cities between 38,000 and 483,000 inhabitants are considered to be centre cities, because they service a wider region. Antwerp and Ghent are the only two real urban cities (resp. 240,000 and 483,000 inhabitants). In particular for the group of small communities, questions are raised with regards their governance capacity.

The Flemish coalition agreement and the green paper (see Box 5 above) also search for a larger scale, working on the assumption that this is necessary in order for local governments to take up more policy responsibilities. Yet, this larger scale is only very reluctantly sought in the merger of communities. The Flemish government provided a framework for voluntary mergers between municipalities, where the Flemish government would pay for a part of the transition costs. In addition, allocation from the municipal fund was guaranteed at the level of the sum of the merging municipalities. Yet, notwithstanding these incentives, not a single merger took place. It appears that local politicians mainly perceive the political risks, and not the potential gains of increasing local governance capacity through mergers.

Mergers are however not the only route towards a larger scale. A first alternative is to create a bigger scale through the merger of municipality and the OCMW. OCMW is an independent social welfare office present in every community. Although the merger is a controversial issue, many municipalities brought together the administrative structure and back-office of both while maintaining an independent policy making capacity. Moreover, policy co-ordination of social policy in municipality and OCMW will be reinforced when from 2013 onwards, the president of the OCMW council will be a mandatory member of the college of mayor and aldermen. 
A second way to increase scale is to seek collaboration and form regional networks. Collaboration by means of urban regions ("stadregionale samenwerkingsverbanden") seems to raise some opportunities. As we discussed above, these collaborations are manifold and are often proof of a local activism to tackle policy problems. Yet, there are also potential problems with efficiency, effectiveness and democratic accountability because of the sheer number of collaborative arrangements. In addition to regional networks, there is a tendency to form networks with comparable municipalities across the territory. There are networks of cities (see for instance the knowledge centre for central cities), rural communities (e.g. the Intergovernmental Rural Consultation (IPO) of the Flemish Land Corporation), and the recently initiated network of small central cities (not belonging to the largest 13 cities).

A third way is to decentralize more competences to local governments. In this way, a bigger scale is obtained in depth, rather than by expanding the working area of municipalities. The decision here lies mainly in the hands of the Flemish government. In any case, a circular reasoning should be avoided, where local governments cannot acquire new competences because they are too small while acquiring new competences would be the main route to get to this bigger scale.

\section{Institutional Mapping}

A final element of the Flemish reform of state is institutional mapping. This mapping is in essence a first step in the implementation of what will be decided. The details are not yet finalised, although some ideas are found in the notes of The Flemish advisory council for Public Administration (VLABEST), a strategic advisory body that formulated several notes on this issue.

The purpose of the screening is first to make an inventory of the networks active in a particular region. This inventory should differentiate between the more heavy weight and more light weight formula of collaboration. Secondly, the mapping process should evaluate the regional networks based on the criteria of legitimacy, efficiency and effectiveness. Thirdly, an action plan per region should be drafted that selects actions from a broad menu of possible instruments to improve the regional governance. This list is not yet decided upon, but the actions that are proposed by VLABEST could be an indication (see below). Finally, the action plan should have sufficient local support - although unanimity may be hard to reach. VLABEST proposes to have it approved by at least $75 \%$ of the municipalities in the region, that together represent $75 \%$ of the population. Once approved, the Flemish government and others should have the power to impose the decisions. The action plan should be translated into a regional contract between local, provincial and Flemish government. 


\section{Box 6. List of actions within regions that may improve regional governance and local governance capacity (based on VLABEST 2010)}

- Consultation and co-ordination within a region (if needed across borders of provinces)

- Small scale contractual cooperation (if needed across borders of provinces)

- Shared services; between municipalities and OCMW and/or between municipalities

- $\quad$ Strengthening municipal government and administration

- $\quad$ Mergers (if agreed upon in the action plan)

- Review of municipal borders ${ }^{5}$

- $\quad$ Reducing the number of regional networks

- Initiate new collaborative arrangements (if needed, different municipalities can take up responsibility for network co-ordination for different subjects)

- Co-ordination of working areas of collaborations (if needed over borders of provinces)

- Clustering of tasks of different collaborations (if needed in a new encompassing structure)

In order to initiate such an institutional mapping, a provisory demarcation of the regions is needed. VLABEST proposed a demarcation that is the common denominator of current circumscriptions; RESOCs and the regional tables (streektafels) within RESOC , care regions, zones for emergency services (such as the fire brigade), Centres for General Welfare (CAW's), intermunicipal associations for regional development (intercommunales voor streekontwikkeling), area based services of the provinces, the consultation of mayors of the municipal association (burgemeestersoverleg), etc. The analysis is not based on socio-demographic research, and hence does not have a scientific character. VLABEST proposes only to use it as a starting point for the mapping process. After this process is complete, the map can be altered if needed. Despite support for the VLABEST map within the green paper and from the Social and Economic Council of Flanders (SERV), a point of critique was that it would not be desirable to organize SERR/RESOC along the lines of the 24 regions (SERV 2010).

The institutional mapping exercise will also take local labour market policies into account. It will focus on several issues of relevance to this study: the issue of how to work across policy sectors at a regional level, how to be parsimonious with institutional structures, how to guarantee and reconcile democratic accountability upwards (to Flanders) and downwards (towards the municipalities), and how to assure that collaboration is producing results in terms of better effectiveness but also efficiency.

\footnotetext{
${ }^{5}$ The previous merger of municipalities in Belgium took place in 1976. This operation was centrally led and reduced the number of municipalities from 2,359 to 596 (of which 308 in Flanders). The process was notoriously political, which lead in some cases to rather incoherent mergers. This could be remedied. The province of Limburg for instance has one RESOC/SERR which includes 5 streektafels. The VLABEST map proposes to initiate a screening within five regions that have the same working area as the streektafels.
} 
Figure 6. Example of Definition of Sub-regions for Sub-regional Institutional Mapping

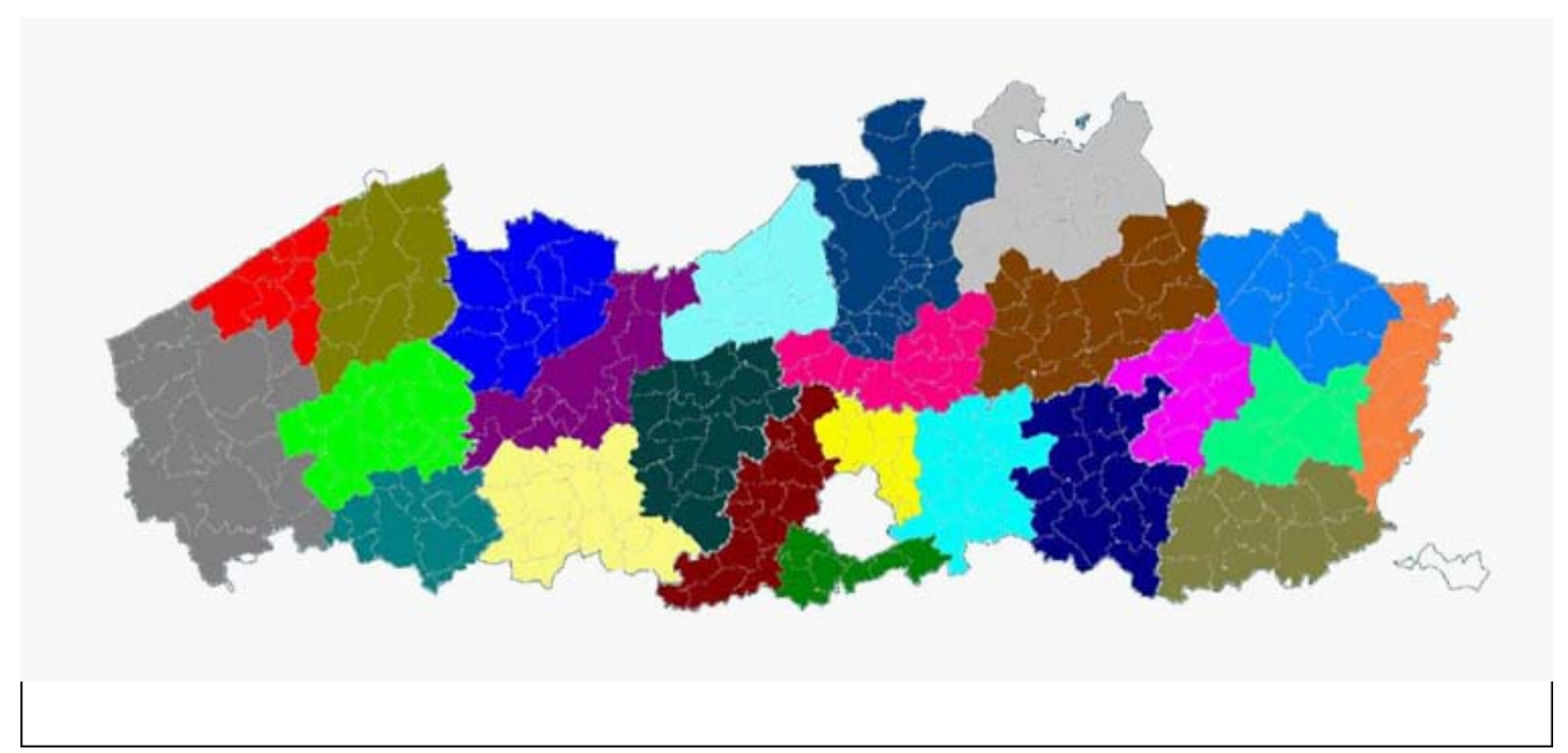

Source: VLABEST 


\section{CONCLUSIONS AND ISSUES FOR CONSIDERATION}

Assessing the sub-regional flexibility available to local employment agencies in Flanders within the framework of the OECD criteria indicates that there is still room for further flexibility at the local level in the management of programmes, budgets, eligibility, performance management and outsourcing. Greater flexibility in these management areas could help labour market policy to contribute more fully to local social and economic strategies. At the same time, new flexibility would have to be combined with continued mechanisms for maintaining accountability, to both central government and to other policy actors at the local level. This may be challenging to achieve in what has become a very complex overall governance framework.

When OECD LEED evaluated the flexibility available to Public Employment Service bodies in Belgium back in 2008, Belgium ranked $2^{\text {nd }}$ in terms of the flexibility it allocated to its regional level (i.e. Flanders, Wallonia, Brussels). However, it came $19^{\text {th }}$ out of the 25 countries in terms of how much flexibility it gave to employment agencies operating at the local level.

Flanders still operates a relatively centralised PES. Employment and activation measures are designed and financed on federal and regional level but are implemented at the local or sub regional level. The 13 regional labour market offices of VDAB (which corresponds to the OECD definition of a local labour market ${ }^{6}$ ) seem to have relatively limited flexibility in the way that they spend their budgets. It is possible to outsource locally but most tendering is centralised, and locally specific tenders are also often decided at the central level. On the other hand, directors of regional labour market offices have some freedom in allocating resources to programmes and activities, as long as they contribute to centrally defined performance targets. Because of its relatively centralised management design, the VDAB system is clearly an efficient organisation in meeting the needs of individuals and firms, and this is welcomed by the social and sectoral partners at the level of the Flanders government. However, it may make the organisation less adaptable to tackling opportunities and challenges at the level of local communities and local labour markets. There appears to be some mismatch in the priorities of the PES Flanders and the overriding issues found in particular labour markets such as Kortrijk and Antwerp.

Within the overall framework, the VDAB clearly makes a strong effort to be both collaborative and active at the local level, an attitude supported by an emphasis on openness from the leadership of the organisation. There is also clearly some room for discretion by local offices. The Local Project Programme in particular is a useful tool for stimulating local initiative, although the budget appears relatively limited and there could be scope for expansion - the OECD has found that elsewhere countries such as Austria, Germany and New Zealand allocate between $10-15 \%$ of their budgets to this type of measure (OECD, 2008) ensuring that local projects can be brought to critical scale. It may also be useful to consider mainstreaming successful local projects into normal VDAB policies and programmes as opposed to preallocating monies each year from the Local Project Programme pot to keep them going - this would free up further funds for local innovation to meet emerging needs. Obviously, the budget spent at local level is only one dimension of local flexibility.

\footnotetext{
${ }^{6}$ See Froy, F and S. Giguère, OECD (2009)
} 
The VDAB currently operates within a situation of relative institutional complexity. The institutional framework on local labour market policy has been created in relatively piecemeal fashion by consecutive state reforms and incrementalism in Flemish policy making. The partnership agreement between the Federal, Flemish and local governments, with the intention of enhanced cooperation, are clearly adding to an already crowded set of networks, and the blueprints and criteria for collaboration do not always appear to fit well with local contexts. Informal networks between local partner institutions are useful in getting things done on a day to day basis. However in order to achieve effective local collaboration it may be useful to consider how the number of formal partnerships and formal collaboration processes imposed from the top down could be reduced. Where central local partnerships are defined, they should be flexible enough to be tailor-made to local areas, reflecting both the different networks already in place and the nature of local labour market contexts.

Despite the plethora of partnerships and networks, until recently, many local networks involving VDAB seemed primarily to serve circulation of information (what are we doing?) or coordination purposes (who does what?). Collaborative networks that develop a joint policy and implement joint actions for a local labour market (focusing on what will we do?) seem to be rare. In addition, VDAB seems to be primarily willing to enter networks with what it considers to be equivalent partners (i.e. the cities of Antwerp and Ghent). Rewarding the contribution of VDAB and NEO offices to broader local employment strategies could be one way of ensuring that collaboration creates more concrete results in practice at local level.

\section{On flexibility and accountability in the management of labour market policy}

The current reform of the VDAB to bring management responsibility from the 13 regional offices (with 13 directors) to 5 provincial offices (with 5 directors) could be a useful opportunity to create more flexibility and strategic responsibility for the VDAB at sub-regional level. Flexibility could be added by providing regional managers with more power to contribute to strategic and integrated employment plans in collaboration with other actors. In order for this flexibility within a larger organisational scale to work, VDAB will have to find ways of dealing with non-equivalent partners in terms of budgets and capacity (such as small municipalities). Moreover, the performance contracts of the provincial directors may have to be more flexible, and require them to take differences in local labour markets into account when delivering policies and programmes. Bringing the training and employment arms of the VDAB to the same geographical level also presents an opportunity to create more alignment between these two policy areas in individual provinces.

The multi annual plans of the municipalities and city governments, proposed under the new Flemish internal State Reform, could provide an excellent opportunity for VDAB to have a single point of influence and integration in local municipal strategies to support employment and economic development. Such strategies should have more critical mass to address the entrenched problems which affect different parts of Flanders, such as high youth and immigrant employment in Antwerp and skills and labour shortages in Kortrijk. The VDAB would clearly find it difficult to address such longstanding issues alone. However this may be difficult to achieve if the regional mangers at provincial level are working with a larger catchment area than individual cities.

Large cities like Antwerp and Ghent seem to stand out in relation to other local governments in terms of scale, governance capacities, and the characteristics of the local labour market. Taking this into account, it might be more effective for the cities of Antwerp and Ghent to also have more strategic VDAB offices, at the same management level as the provincial offices. The introduction of city managers introduces some opportunities here. At a later stage, it might be useful to extend this to other urban regions. Another possibility is to hold provincial directors accountable for their responsiveness not only to overall local labour market conditions, but also to differences within their province. Provincial directors could give city 
managers more leeway to tailor services to meet city needs and to meet the objectives elaborated in local city strategies - maybe under the auspices of a city contract. A similar formula may apply for other specific local labour market conditions in provinces (for example allocating a Mining Area Manager for the 10 or so municipalities in Limburg that were confronted with mine closure in the 1980s). The formula of more adaptive policies, contracting out and project based operations under the umbrella of strong provincial VDAB offices has the advantage of being flexible and adaptable, without requiring additional organisational reform.

\section{Maintaining Accountability}

The move towards outcome-based approach to performance management in the VDAB promises to provide greater leeway to local VDAB offices while preserving the achievement of province wide goals. At the same time, the fact that the VDAB sees target setting as a factor in creating a learning environment as opposed to a sanctioning one has been identified by some as a promising way of dealing with performance measurement (Van Dooren, Bouckaert \& Halligan, 2010; Van Dooren \& Van de Walle 2008).

There are a number of ways in which outcome targets can be managed flexibly while still achieving good reporting on results (numbers trained, numbers attending interviews etc) from the bottom up. In Alberta, Canada, for example, local employment agency staff are allocated broad strategic priorities (without specific targets) which they negotiate according to local needs. They then report back on the degree to which they have met these strategic objectives on a quarterly basis while the province also collects additional information on the programmes implemented/individuals served and employment outcomes. There is therefore a great deal of feedback in the system, but overly stringent output targeting for lower level staff is avoided. This system relies in part on strong levels of communication between the provincial and local staff which may be less easy to achieve within a larger performance management system however (Alberta has a population of 4 million, for example, with six regional offices and six regional directors and 59 delivery sites across the province). In Flanders, the strong communication which exists between central and sub-regional managers (and which should only increase following the 'provincialisation' of the VDAB) could also support such a process.

Another possibility which Flanders could consider is supporting sub-regional or provincial VDAB offices to set extra targets in agreement with other local partners for which they would then be resourced and evaluated. In Texas in the United States, for example, local Workforce Investment Boards are asked to set additional targets to those set at "baseline" by the state, based on local strategic priorities through a two-tier system of "formal" and "less formal” measures. Formal measures are consistent across workforce programmes, while less formal measures are often outcome based and consistent with local strategic plans. Local workforce boards report to the state on both sets of measures.

In the broader international study, OECD LEED has looked at the possibility of balancing vertical lines of accountability with horizontal ones. Ensuring that local PES offices are accountable to local boards made up of politicians and representatives of relevant local agencies is one example. For example in Denmark, local jobs centres are overseen by local employment councils which share knowledge, expertise and resources, and also play a role in helping to draft local employment policies and programmes (OECD, 2010). However, given the myriad of different organisations involved in developing, overseeing and delivering labour market policy in Flanders, achieving effective horizontal accountability mechanisms may be complicated to achieve in practice. 


\section{Linking strategy with policy and practice at sub-regional level}

At the sub-regional level, tripartite consultation platforms called RESOC and SERR analyse the local labour market context and develop a regional employment plan (streekpact). However at the moment the strategic planning which takes place at the levels of the RESOC and SERR appears only weakly to feed into the development of policies and programmes, in an ad hoc fashion. In addition, the quality of the strategic plans appears to be highly variable. Some RESOC's use European money and other means to get their projects adopted, yet, some concerns remain with regards to the continuity of project-funded initiatives. There seems to be a lack of close working with the VDAB at a local level. The research by the RESOC and SERR into local labour market challenges and opportunities is clearly valuable. However in the future, it should be evaluated whether this is the right level for information to be collected and strategies planned, if there is not a clear link back into the policy development process.

\section{Cutting across policy silos}

In order to tackle the complex issues which can hold back individuals from getting into work at one end of the scale, and can prevent local economies from developing, at the other, labour market agencies cannot work alone. It is therefore not just labour market policy that needs to be flexible. In Flanders, it is clear that the compartmental nature of government has not helped when trying to tackle difficult issues in a holistic manner at local level, whether it be childcare, mobility challenges or skills shortages. An OECD LEED study on the degree of local integration between economic development, skills and employment policies in 11 countries (Froy and Giguère, 2010) identified a number of recommendations for better aligning policies. Policy integration does not necessarily require institutional change at the local levelindeed too much institutional change can be self-defeating. In countries such as the United Kingdom, Italy and the United States, just as in Flanders, many years of institutional reform to achieve different policy objectives has often lead to a complex multi-layering of organisations, partnerships and initiatives and a confusion regarding roles and responsibilities at the local level, detracting from, as opposed to consolidating, policy integration. What is needed across the board is rather a change in working practices and a "refocusing of government".

In Flanders, a number of attempts have been made to help break out of policy silos through emphasizing both a client perspective and an area based perspective. In particular, public services have been encouraged to organise service delivery to address the needs of 'the client' broadly defined; youth, elderly, tax payers, newcomers. In relation to labour market policy, the question is 'who is the client?' is important, however. While for the VDAB it may be the individual unemployed person or a firm, for other stakeholders such as municipalities, the perspective may be towards the city or town as a whole, as an attempt is made to meet broader community needs and build a high quality labour force for the future. While municipalities may be looking at employment policy in the latter perspective, local employment agencies such as the VDAB and the NEO are often forced to concentrate more on individual clients and firms. This can make it difficult when aligning strategies and action plans. An equally challenging question for labour market policy is 'what is the area?'. Collaboration has been supported at many different governance levels in Flanders until now, making the labour market policy planning process very complicated. More reflection on the right level for implementing labour market policy is useful - what needs to be done at the level of a 'travel to work area' and what needs to be done at the level of the neighbourhood?

\section{Raising capacities}

Finally, building capacities is also an important issue in Flanders. The available resources at the sub regional level to design and implement local labour market policies are limited, not only for VDAB but also for RESOC/SERR and local governments. Additional resources can be found in partnerships or 
external subsidies. However, applications for extra resources impact on available capacity (time, personnel) within organisations. A "chicken and egg" situation appears to exist in relation to capacities at the local level. More central governments fear that local capacities are low and are reluctant to offer new responsibility and hence new resources. However, without gaining responsibility and a degree of control over policy implementation, local actors often have little opportunity to build their competences (see Froy, F., \& Giguère, S., 2010). The same may apply to the situation of municipalities in Flanders. The United States Department of Labor has put in place a useful mechanism for providing greater flexibility incrementally to those local areas that have a proven capacity to deliver. In the United States, a "waiver" system has been established by the Department of Labor to allow states to apply for additional flexibility in specific areas when implementing innovative workforce strategies and initiatives. Many states have taken advantage of the system, with 331 being approved by 2006. Texas, for example, has obtained waivers to expand the target group of people eligible for training and to relax the required $50 \%$ employer match for customised training. Incremental flexibility could be useful in Flanders to give additional responsibilities to municipalities which already have a capacity to deliver, while encouraging others to also build their critical mass. 


\section{ANNEX 1: LIST OF ABBREVIATIONS}

\begin{tabular}{|c|c|}
\hline DISPO & $\begin{array}{l}\text { Procedure of the NEO to activate the job seeking } \\
\text { attitude of the unemployed (Activering van het zoekgedrag) }\end{array}$ \\
\hline EFRO & $\begin{array}{l}\text { Europees Fonds voor Regionale Ontwikkeling } \\
\text { (European Fund for Regional Development) }\end{array}$ \\
\hline ERSV & $\begin{array}{l}\text { Erkend Regionaal Samenwerkingsverband } \\
\text { (Acknowledged Regional Cooperation) }\end{array}$ \\
\hline ESF & $\begin{array}{l}\text { Europees Sociaal Fonds } \\
\text { (European Social Fund) }\end{array}$ \\
\hline GTB & $\begin{array}{l}\text { Gespecialiseerde } \\
\text { Begeleidingsdienst } \\
\text { (Specialised Labour Counselling Services) }\end{array}$ \\
\hline JAP & $\begin{array}{l}\text { Jaarlijks Actieplan } \\
\text { (VDAB yearly action plan) }\end{array}$ \\
\hline JOP & $\begin{array}{l}\text { Jaarlijks Ondernemingsplan } \\
\text { Yearly Business Plan (of the VDAB) }\end{array}$ \\
\hline OCMW & $\begin{array}{l}\text { Openbaar Centrum voor Maatschappelijk Welzijn } \\
\text { (Public Social Assistance Centre) }\end{array}$ \\
\hline POM & $\begin{array}{l}\text { Provinciale OntwikkelingsMaatschappij } \\
\text { (Provincial Development Agency) }\end{array}$ \\
\hline PWA & $\begin{array}{l}\text { Plaatselijk WerkgelegenheidsAgentschap } \\
\text { (Local Employment Agency) }\end{array}$ \\
\hline & $\begin{array}{l}\text { Regionaal Sociaal-Economisch Overleg Comité } \\
\text { (Regional Socio-Economic Committee) }\end{array}$ \\
\hline
\end{tabular}




\begin{tabular}{|c|l|}
\hline RVA & $\begin{array}{l}\text { Rijksdienst Voor Arbeidsvoorziening } \\
\text { (National/Federal Employment Office) }\end{array}$ \\
\hline SERR & $\begin{array}{l}\text { Sociaal-Economische Raad van de Regio } \\
\text { (Socio-Economic Council of the Region) }\end{array}$ \\
\hline VDAB & Vlaamse Dienst voor Arbeidsbemiddeling \\
& (Flemish Public Employment Service) \\
\hline VVSG & Vlaamse Vereniging van Steden en Gemeenten \\
& (Flemish Association of Cities and Municipalities) \\
\hline WIP & Werk en InvesteringsPlan \\
& (Work and Investment Plan) \\
\hline
\end{tabular}




\section{ANNEX 2: INTERVIEWEES AND ROUNDTABLE PARTICIPANTS}

\section{Interviewees}

- $\quad$ Fons Leroy, Managing Director of the VDAB

- Annick Waegeman, Department of Work, City of Antwer

- Alain Depreux, Co-ordinator SERR/RESOC Kortrijk

- Peter De Ridder, Co-ordinator SERR/RESOC Mechelen

- $\quad$ Peter Cousaert and Fabio Contipelli, VVSG

- Ann Van Den Cruyce and Marc Haesendonckx, Department of work, Flemish Government

\section{Roundtable participants}

Participants list: Kortrijk

\begin{tabular}{|l|l|l|}
\hline & Representative & Organisation \\
\hline & Alain Depreux & RESOC South West Flanders \\
\hline & Antoon Vermeulen & VDAB Competentiecentrum \\
\hline & Axel Ronse & UNIZO \\
\hline & Dirk Claus & Stad Kortrijk \\
\hline & Erik Bouckaert & VDAB West-Flanders \\
\hline & Franky Roels & ABVV en voorzitter SERR ZWVL \\
\hline & Gert Thienpont & LVD \\
\hline & Griet Opsomer & vZW Waak (beschutte werkplaats) \\
\hline & Jean-Claude Christiaens & Wienerberger.nv -divisie Pottelberg -HR \\
\hline & Marc Fourneau & OCMW Waregem, Public Social Assistance \\
& Centre \\
\hline & Marc Verpoort & AZ Groeninge ziekenhuis (Hospital) \\
\hline & Mathieu Marisse & VOKA \\
\hline & Piet Lareu & Mentor \\
\hline & Stefanie Clinckemaillie & RESOC/SERR Zuid-West-Vlaanderen \\
\hline & Tatjana Samaey & Fonds voor vakopleiding bouwsector \\
\hline & Veerle De Mey & VOKA \\
\hline
\end{tabular}


Participants list: Antwerp

\begin{tabular}{|l|l|l|}
\hline & Representative & Organisation \\
\hline & Ann Neels & $\begin{array}{l}\text { OCMW Antwerpen, Public Social Assistance } \\
\text { Centre }\end{array}$ \\
\hline & 'active City', City of Antwerp \\
\hline & Ingrid Mertens & $\begin{array}{l}\text { VDAB Antwerpen, coordinator labour } \\
\text { mediation }\end{array}$ \\
\hline & Jan Van Den Eynde & ACV Antwerpen \\
\hline & Marina Van Den Bulck & ABVV \\
\hline & Mario Schelfaut & RESOC Antwerpen \\
\hline & Peggy Van den Steen & $\begin{array}{l}\text { VDAB, Labour Market direction } \\
\text { Flemish public employment service }\end{array}$ \\
\hline & Peter Stappaerts & Werkhaven \\
\hline Petra Van Golen & $\begin{array}{l}\text { Ministry of SZW } \\
\text { Senior policy consultant }\end{array}$ \\
\hline & Stefan Rooms & Expert economy, city of Antwerp \\
\hline & Michel Moermans & City of Ghent, department of Work \\
\hline
\end{tabular}

Participants list: Brussels

\begin{tabular}{|l|l|l|}
\hline Representative & Organisation \\
\hline & Ann Van Den Cruyce & $\begin{array}{l}\text { Head department employment, Flemish } \\
\text { government }\end{array}$ \\
\hline & Anneleen Peeters & Cabinet of the Flemish Minister of work \\
\hline & Arne Fockaert & SLN \\
\hline Christ Vanneste & ABVV \\
\hline Fabio Contipelli & $\begin{array}{l}\text { VVSG, Flemish organization of cities and } \\
\text { communities }\end{array}$ \\
\hline & Francis Devisch & SERV \\
\hline Marc Haesendonckx & $\begin{array}{l}\text { department employment, team labour market } \\
\text { policy and activation, Flemish government }\end{array}$ \\
\hline & Paul Verschueren & \begin{tabular}{l} 
Federgon \\
\hline Peggy Van den Steen
\end{tabular} \\
& $\begin{array}{l}\text { VDAB, Labour Market direction } \\
\text { Flemish public employment service }\end{array}$ \\
\hline Peter Cousaert & $\begin{array}{l}\text { VVSG, Flemish organization of cities and } \\
\text { communities }\end{array}$ \\
\hline & ACV \\
\hline & Peter Van Der Hallen & $\begin{array}{l}\text { VDAB, Teamleader Strategic policy support } \\
\text { Flemish public employment service }\end{array}$ \\
\hline
\end{tabular}




\section{BIBLIOGRAPHY}

Bogaerts, Kristel, Ive Marx, D. Vandelannoote, \& Natascha Van Mechelen (2010). Activering bij werkloosheid en recht op maatschappelijke integratie. Onderzoek in opdracht van de FOD Werkgelegenheid, Arbeid en Sociaal Overleg. Antwerpen : Universiteit Antwerpen.

Bouckaert, G., \& Halligan, J. (2008). Managing Performance: International Comparisons. London: Routledge.

De Cuyper,P., Lamberts, M. and Struyven, L. (2008), Creatief met knelpunten op de arbeidsmarkt. Een inventarisatie van vernieuwende praktijken. Leuven: Katholieke Universiteit Leuven. Hoger instituut voor de arbeid.

De Rynck, F. (2010). Sterk besturen in een sterke regio: Inventaris regionale samenwerkingsverbanden in zuid-west Vlaanderen. Kortrijk: Leiedal. Leuven: Katholieke Universiteit Leuven. Hoger instituut voor de arbeid, 2008, 122 p.

De Rynck, F. (2011). Evaluatie van de samenwerkingsverbanden in de regio Kortrijk. Regioscreening op enkele domeinen. discussietekst. Kortrijk.

Froy, F., \& Giguère, S. (2010). Breaking Out of Policy Silos: Doing More with Less (No. 9264094989). Paris: OECD Local Economic and Employment Development (LEED)

Giguère, S and F. Froy OECD (2009), Flexible Policy for More and Better Jobs, OECD, Paris.

RVA (2009), RVA jaarverslag 2008. Brussel: Rijksdienst voor arbeidsvoorziening.

SERV (2007), Advies. Besluit betreffende de Lokale diensteneconomie. Brussel.

Struyven, L., Van Hemel, L. (2007), Naar één loket voor werk. Evaluatie van de ruimtelijke spreiding, het gebruik en het partnerschap van de werkwinkel. Deelrapport 2, Leuven: Katholieke Universiteit Leuven. Hoger instituut voor de arbeid.

Stuyck, K., Van Hecke E. (2006), Naar één loket voor werk. Ruimtelijke optimalisatie en evaluatie van de huidige lokalisatie van de werkwinkels. Deelrapport 1, Leuven: Katholieke Universiteit Leuven.Onderzoeksgroep Sociale en Economische Geografie.

Van Dooren, W. \& Van de Walle, S. (eds.), Performance Information in the Public Sector, Basingstoke: Palgrave Macmillan, 277p.

Van Dooren, W., Bouckaert, G. \& Halligan, J. (2010), Performance Management in the Public Sector, London/New York: Routledge, 198p.

Vlaams minister van Financiën, Begroting, Werk, Ruimtelijke Ordening en Sport (2009), Beleidsnota werk 2009-2014. Een nieuwe arbeidsmarktvisie voor Vlaanderen. Brussel. 